\title{
Risk-based damage potential and loss estimation of extreme flooding scenarios in the Austrian Federal Province of Tyrol
}

\author{
M. Huttenlau ${ }^{1,2}$, J. Stötter ${ }^{1,2}$, and H. Stiefelmeyer ${ }^{3}$ \\ 1 alpS - Centre for Climate Change Adaptation Technologies, Innsbruck, Austria \\ ${ }^{2}$ Institute of Geography, University of Innsbruck, Innsbruck, Austria \\ ${ }^{3}$ Federal Water Engineering Administration, Federal Ministry of Agriculture, Forestry, Environment and Water Management, \\ Vienna, Austria
}

Received: 14 September 2009 - Revised: 12 September 2010 - Accepted: 17 September 2010 - Published: 3 December 2010

\begin{abstract}
Within the last decades serious flooding events occurred in many parts of Europe and especially in 2005 the Austrian Federal Province of Tyrol was serious affected. These events in general and particularly the 2005 event have sensitised decision makers and the public. Beside discussions pertaining to protection goals and lessons learnt, the issue concerning potential consequences of extreme and severe flooding events has been raised. Additionally to the general interest of the public, decision makers of the insurance industry, public authorities, and responsible politicians are especially confronted with the question of possible consequences of extreme events. Answers thereof are necessary for the implementation of preventive appropriate risk management strategies. Thereby, property and liability losses reflect a large proportion of the direct tangible losses. These are of great interest for the insurance sector and can be understood as main indicators to interpret the severity of potential events. The natural scientific-technical risk analysis concept provides a predefined and structured framework to analyse the quantities of affected elements at risk, their corresponding damage potentials, and the potential losses. Generally, this risk concept framework follows the process steps hazard analysis, exposition analysis, and consequence analysis. Additionally to the conventional hazard analysis, the potential amount of endangered elements and their corresponding damage potentials were analysed and, thereupon, concrete losses were estimated. These took the specific vulnerability of the various individual elements at risk into consideration. The present flood risk analysis estimates firstly the general exposures of the risk indicators in the study area and secondly analyses the specific exposures and consequences of five extreme event scenarios. In order to precisely identify, localize, and characterize the relevant risk indicators of
\end{abstract}

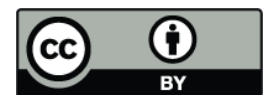

Correspondence to: M. Huttenlau (huttenlau@alps-gmbh.com) buildings, dwellings and inventory, vehicles, and individuals, a detailed geodatabase of the existing stock of elements and values was established on a single object level. Therefore, the localized and functional differentiated stock of elements was assessed monetarily on the basis of derived representative mean insurance values. Thus, well known difference factors between the analysis of the stock of elements and values on local and on regional scale could be reduced considerably. The spatial join of the results of the hazard analysis with the stock of elements and values enables the identification and quantification of the elements at risk and their corresponding damage potential. Thereupon, Extreme Scenario Losses (ESL) were analysed under consideration of different vulnerability approaches which describe the individual element's specific susceptibility. This results in scenario-specific ranges of ESL rather than in single values. The exposure analysis of the general endangerment in Tyrol identifies (i) 105330 individuals, (ii) 20272 buildings and 50157 dwellings with a corresponding damage potential of approx. EUR $20 \mathrm{bn}$. and (iii) 62494 vehicles with a corresponding damage potential of EUR $1 \mathrm{bn}$. Depending on the individual extreme event scenarios, the ESL solely to buildings and inventory vary between EUR $0.9-1.3 \mathrm{bn}$. for the scenario with the least ESL and EUR 2.2-2.5 bn. for the most serious scenarios. The correlation of the private property losses to buildings and inventory with further direct tangible loss categories on the basis of investigation after the event in 2005, results in potential direct tangible ESL of up to EUR $7.6 \mathrm{bn}$. Apart from the specific study results a general finding shows that beside the further development of modelling capabilities and scenario concepts, the key to considerably decrease uncertainties of integral flood risk analyses is the development and implementation of more precise methods. These are to determine the stock of elements and values and to evaluate the vulnerability or susceptibility of affected structures to certain flood characteristics more differentiated. 


\section{Introduction}

Worldwide reinsurance companies are recording a pronounced increase of flood related losses. Beside windstorms, floods are the most frequent cause of natural hazard losses. Moreover, there is evidence that on a global scale flood risks and flood losses will increase in the future (Kron, 2004). This correlates with the identification of a world-wide upward trend in vulnerability to flooding due to altered frequencymagnitude relations and an increased exposure of humans and their properties (Munich Re, 2007). Analogue to the global scale, the predicted trend can also be observed on a regional scale in the proximity of the study area in Southern Germany (Hennegriff et al., 2006). In the last decades flood events caused serious losses in Europe (e.g. in 1997, 1999, 2000, 2002, and 2005) whereas Austria was highly affected in 1999, 2002, and 2005. In the study area Tyrol, some serious flooding events have taken place over the last decades, like in 1965, 1966, 1985, 1986, 1987, 1999, and 2005 (e.g. Blättler, 1995; BMLFUW, 2006; IWHW, 2006; Meier, 2002). Thereby, especially the 2005 event has induced serious losses in Tyrol.

While considering the impacts of flood events on society, decision-makers have to face, additionally to design events and annually expected loss topics, the question of assumed losses due to extreme events. This is necessary for the implementation of appropriate risk management strategies. In this context, insurance companies need to be aware of their portfolio specific accumulative loss potential and thereupon linked liability consequences in order to underwrite appropriate reinsurance coverages. Moreover, the spatial affectedness and the thereupon derived loss dimensions of extreme scenarios are important information for public authorities and politicians. Such expertises affect spatial planning topics under remaining risk aspects, preventive strategies in the context of non-insurance risk transfer mechanisms, and legal frameworks concerning natural hazard related insurance solutions. Additionally, extreme event scenarios can describe input scenarios for emergency management strategies of civil protection organisations.

The natural scientific-technical risk approach provides a predefined structured and standardized framework to analyse the potential consequences of natural hazard events. Thereby, the following analysis modules are applied consecutive: hazard analysis, exposition analysis, and consequence analysis (e.g. Heinemann et al., 1998; Hollenstein, 1997; Kienholz, 2005). This approach contains the term risk, which can be generally described as a product of hazard, elements at risk, and vulnerability (e.g. Bohle and Glade, 2008; Kleist et al., 2006; Papathoma-Köhle et al., 2007). Thereby, risk analyses aim at estimating the negative consequences in terms of damages or losses of a potentially dangerous natural process to society or parts of society (Douglas, 2007; Fuchs, 2009). These monetary values of damages or losses can somehow be interpreted as comprehensible and generally accepted substitute dimensions for the quantification of the analysed risk.

The target of the present study is to analyse the elements at risk with their corresponding damage potentials and assumed losses of extreme flooding scenarios in the Austrian Federal Province of Tyrol on a regional study scale. It is inherent to the regional scale approach, that the results are understood as accumulative consequences of all affected elements. In contrast, studies on local scales focus solely on single objects. Beside the general exposure of risk indicators to flood endangered areas the main target focuses on potential consequences of extreme flooding scenarios. Thereby, the elements at risk are understood as the quantitative exposure of elements such as buildings, dwellings, vehicles, or individuals. The damage potential evaluates the monetary values of these exposed elements, while the losses are estimated as a functional relationship of the identified object's susceptibility (or vulnerability) dependent on the hazard magnitude (in this case the water depth). In the context of risk analyses the term Probable Maximum Loss (PML) is often applied to emphasize the extreme or worst-case event character. However, this term is mostly not clearly defined and somehow anticipates the biggest monetary loss that could result from a catastrophe, but is usually used in connection with property and liability topics. Moreover, the general existing definitions are interpreted as "little big vague" from a mathematical perspective (Kremer, 1990: p. 201), and, therefore, detailed mathematic discussions on PML in connection with insurance risks were undertaken (e.g. Kremer, 1990, 1994). In order to avoid critical discussions on this topic but to emphasize the extreme event character of the considered scenarios the present study understands the analysed losses resulting from extreme flooding scenarios as Extreme Scenario Losses (ESL).

The present study was realised in co-operation with alpS - Centre for Natural Hazard and Risk Management in Innsbruck (Austria) (since April 2010, alpS - Centre for Climate Change Adaptation Technologies), both the Institute of $\mathrm{Ge}$ ography and the Institute of Public Finance (University of Innsbruck, Austria), as well as the Tiroler Versicherung (Tyrolean Insurance Company). Considerating the various interests of the involved stakeholders the study generally focuses on the risk indicators of buildings, dwellings and inventory, vehicles, and individuals within the exposure analysis. The consequence analysis concentrates mainly on buildings, dwellings and inventory as most property loss relevant risk indicators of insurance companies. Additionally, vehicles were considered to take the proportion of motor insurance contracts within the portfolio of insurance companies into account. In order to point out the uncertainties and highlight the linked consequences of at least vulnerability approaches an ESL range (instead of a single absolute value) was estimated based on different vulnerability approaches. Beside the present risk analysis, which considers the consequences 
on the scale of the entire federal province, a detailed portfolio analysis (including liability consequences) for the specific portfolio of the involved insurance company was executed.

The study area, the Austrian Federal Province of Tyrol is situated in the western part of Austria, a central part of the Eastern Alps, with the highest point at $3772 \mathrm{~m}$ (Wildspitze) and the lowest point at $465 \mathrm{~m}$ (Erl, border to Germany). Thereof, only $11.8 \%$ of the total area of the province $\left(12648 \mathrm{~km}^{2}\right)$ are defined as area of permanent settlement (area which is designated for intensive use of settlement, agriculture, and traffic) (Amt der Tiroler Landesregierung, 2009). Moreover, Alpine regions are characterized by the concentration of elements and values situated particularly in the valleys floors. In the study area the highest population densities and associated values can be found in the main Inn River valley and the valleys with a predominantly tourism based economy. This initial situation forms the basis for an extensive conflict potential concerning the initial conditions of the hazard potential and the existing stock of elements and values. The present study enables the quantification of potential loss dimensions due to extreme flooding scenarios and the further consideration of the results as one of different information sources for appropriate risk management strategies.

The following article gives at the beginning a state-of-theart review concerning the risk concept in general and (regional) flood risk analysis procedures. On the background of this overview methods and results of the study are described and a discussion and conclusion chapter rounds the paper.

\section{State-of-the-art}

Generally, the term risk is not uniformly defined, but instead different risk perceptions and concepts exist. Therefore, the following paragraph discusses the state-of-the-art of risk comprehension placing an emphasis on literature relevant to flood risk, where appropriated. A further paragraph focuses on the state-of-the-art concerning (regional) flood risk analyses.

\subsection{The risk concept}

Regarding the existing perceptions and approaches (e.g. Banse and Bechmann, 1998; Weichhart, 2007) risk concepts can be differentiated in: natural scientific (e.g. Kienholz, 2005), engineering (e.g. Melchers, 2002), social scientific (e.g. Renn and Walker, 2008), and economic approaches (e.g. Embrechts et al., 2009). Understanding geography as a discipline focussing on man-environment systems two principle perceptions can be identified with regard to natural hazards (Pohl and Geipel, 2002; Weichselgartner, 2002; Dikau and Weichselgartner, 2005): a process-oriented natural scientifictechnical approach and a social-oriented perceptual and social scientific approach (e.g. Felgentreff and Dombrovsky,
2008; Müller-Mahn, 2005; Müller-Mahn, 2007; Pohl, 2008). According to Müller-Mahn (2007), the differentiation can be made between the epistemological positions of objectivism and constructivism. Unlike to Müller-Mahn (2007), Zahnen (2008) argue that these two perceptions are just one or the other side of the same coin focussing on concrete risks whereby these have to be distinguished from the ontological perception of creeping risks.

Generally and regarding the natural scientific-technical perception the term risk can be described as a product of hazard, elements at risk, and vulnerability (e.g. Bohle and Glade, 2008; Kleist et al., 2006; Papathoma-Köhle et al., 2007). Based on this natural scientific-technical comprehension, risk analyses aim at estimating the negative consequences in terms of damages or losses of a potential dangerous natural process to society or parts of society (Douglas, 2007; Fuchs, 2009). Thereby, the general procedure comprises the methodological modules of hazard analysis, exposition analysis (identification of the elements at risk and the corresponding damage potentials), and consequence analysis (damage or loss estimation). However, while the term risk has been developed and adapted across a wide range of natural scientific and technical disciplines, the potential for misunderstanding exists (Samuels et al., 2009). Especially the distinction between hazard and risk is most important. Thus, the conceptual source-pathway-receptor-consequence (S-PR-C) model (e.g. Dawson, 2003; Samuels et al., 2009) became popular with respect to flood risk topics in recent years. Thereby, the S-P-R-C model follows the above mentioned methodological procedures: source - pathway (hazard analysis), receptor (exposition analysis), and consequence (consequence analysis).

For the assessment and interpretation of risk-based analyses the frequency-magnitude relationships play a key factor. However and especially with regard to extreme events, e.g. hydro-meteorological triggers underlie a natural variability (Merz, 2006) and, therefore, follow the principles of nonlinearity (e.g. Schrott and Glade, 2008) or non-stationarity (e.g. Hall and Solomatine, 2008). According to Kantz et al. (2006), nonlinear stochastic processes are providing the basis of extreme events. In this context, Plate (1992) mentioned that variability is inherent to all natural processes.

The scale and the associated grade of detail and accuracy of risk analyses is strongly correlated with the (spatial) size of the study area, the available data, the technological and temporal options, and the computing power (especially for detailed 2-D and 3-D modelling). From a methodological perspective two different scale-dependent approaches generally exist: analyses on regional and on local scales with their respective corresponding levels of detail (e.g. Glade and Crozier, 2005; Heinimann et al., 1998; Loat and Petraschek, 1997). Especially in the framework of flood risk analyses with a natural scientific-technical background the differentiation between macro-, meso- and microscale approaches is also common (e.g. BWK, 2001; Gewalt et al., 1996; Meyer, 
2005; Schmitke, 1995). However, within recent years these strict differentiations have resulted in controversial discussions and e.g. Meyer and Messner (2005) show that the common macro-meso-micro differentiation and the corresponding loss evaluation methods no longer hold in this strict way.

The representative localisation and quantification of the stock of elements and values has major implications on the uncertainties of the risk analyses results'. Thus, this topic represents a general key factor in the framework of risk analyses but has received only minor attention in the past (Koivumäki, 2010), In contrast to the methodological improvements and thorough discussions especially of hazard analysis approaches but also of vulnerability concepts (Koivumäki, 2010), only a few method descriptions and explicit case-studies are discussed in scientific literature (for more details see e.g. Huttenlau and Stötter, 2008). Hamann and Reese (2000) or Reese and Markau (2004) showed that partially high difference factors of the analysed elements and values are inherent between common methodologically addressed meso- and microscale approaches. Nevertheless, within recent years enhanced technical capabilities and better geo- and statistical data allow a more sophisticated and spatially precise evaluation of the stock of elements and values. For instance, Huttenlau and Stötter (2008) have recently presented a method to estimate the stock of elements and values for a regional study on a detailed object-oriented approach. Thereby, first property-by-property flood risk analyses are already applied on national scale (e.g. Hall et al., 2003).

Most of detailed natural hazard risk analyses do not consider the holistic impacts of a hazardous event to the economy, as generally studies only focus on a limited number of risk indicators according to the overall conditions, the investigation objectives, and the interests of the participating stakeholders. The different risk indicators in general can be classified into direct and indirect damages and further into tangible and intangible damages (e.g. Green et al., 1994; Penning-Rowsell et al., 2003; Smith and Ward, 1998). In this context, all damages related to the immediate hazard impact can be addressed under the term direct damages whereas damages due to the disruption of the economy or parts of the economy as well as emergency and preventive costs are understood as indirect damages. While tangible damages can be relatively easily quantified, intangible damages are not traded in a market and are thus difficult to assess. Most studies with a natural scientific-technical perception are focusing on direct tangible consequences on the built environment. Thereby, with the exception of hail risk analyses, buildings and inventory are the most important (Meyer and Messner, 2007) and, therefore, often the only considered risk indicators whereas a minority of the studies consider additional risk indicators like vehicles, infrastructure, lifelines, agricultural products, and others. To estimate additional indicators e.g. Meyer and Messner (2007) recommend simpler ways such as the correlation with typical damage shares. Moreover, based on the aim and perception of the particular study, financial and economic damages have to be distinguished (Hennegriff, 2008; Merz, 2006). Thereby, financial damages are considered under the assumption that damaged objects have to be replaced (e.g. studies with a property and liability background of the insurance industry) while the assessment on the basis of the depreciated values (the economic damages) is recommended from an economic point of view (e.g. DWA, 2008; Meyer and Messner, 2007; Penning-Rowsell and Green, 2000a; Penning-Rowsell and Green, 2000b). Generally the replacement values and depreciated values differ by a factor of two (Merz, 2006; Meyer and Messner, 2007).

In most cases, vehicles are not considered as discrete risk indicators within risk analyses, although they represent a significant proportion of the potentially exposed values. But, dependent on lead time and human reaction, the losses might be comparably low (Meyer and Messner, 2007). Nevertheless, in the context of loss analyses vehicles represent a considerable risk indicator concerning the proportion of the vehicle asset within the portfolio of insurance companies.

Individuals are seldomly addressed as an explicit risk indicator within natural scientific-technical natural hazard risk analyses. This topic is discussed very controversially and one could argue that the consideration of individuals as a discrete risk indicator is unacceptable from an ethic-moral point of view (e.g. Kok et al., 2004). Furthermore, the complexity, uncertainty and ambiguity of the probability of presence as well as human reactions in extreme situations are hard to quantify and existing approaches are not (yet) expedient applicable (Merz, 2006). Despite the generally controversial discussion on this topic the estimation of the number of people at risk is essential information for decision makers and further catastrophe and risk management strategies. Moreover, some approaches of indirect monetary evaluations of the loss of life in the context of natural hazards can be found in the literature; e.g. Leiter (2006) discusses the willingnessto-pay approach in an overall natural hazard context whereas e.g. Clark et al. (2002), Merz (2006), or Zhai (2007) focuses on flood risks, and e.g. Fuchs and McAlpin (2005) consider the human-capital approach for net benefit analyses of avalanche defence structures.

Like the term risk in general, the term vulnerability is also widely discussed without hitherto a common definition having been accepted (Hollenstein, 2005; Barroca et al., 2006). Fuchs et al. (2007) give a compilation of different definitions of the term vulnerability in the context of natural hazards. Furthermore, Fuchs (2009) discusses structural, economic, institutional, and social vulnerability concepts with respect to mountain hazards in Austria. In this context, the structural vulnerability is understood as the susceptibility of physical structures of affected elements towards process magnitudes. The degree of losses can be estimated by means of functional relationships between the process impact (represented by a proxy for the process magnitude like 
inundation-depth) and the structural damages caused thereby (e.g. Douglas, 2006; Fuchs et al., 2007; Fuchs, 2009; Hollenstein et al., 2002; Hollenstein, 2005). Generally, hazard proxy-damage relationships can be described with absolute or relative damage-functions (e.g. Merz, 2006; Meyer and Messner, 2007). Thereby, the absolute damage function approach applies mean absolute loss values independent of the individual element's value. In contrast, relative damage functions express the loss susceptibility of the specific element at risk under consideration of the individual element's monetary value and structural/physical affectedness. Absolute damage functions have to be well developed, differentiated, and frequently updated. They are more dependent on the type of building or asset under consideration and therefore harder and more uncertain to transfer to other study areas (Meyer and Messner, 2007). Relative damage functions in contrast are easier to transfer to other regions (Meyer and Messner, 2007) and are more appropriate, where the scale of the specific study and/or the existing data basis makes a more detailed functional differentiation impossible. Moreover, the distinction between replacement value and depreciated value approaches is essential. Damage functions can be derived on the basis of observed or synthetic data (DWA, 2008; Green et al., 1994; Penning-Rowsell et al., 2003).

The analysis of single elements at risk is very difficult and uncertain due to the variability within the empirical damage samples and the statistical implications on the thereupon derived damage functions (e.g. IWK, 1999). However, the uncertainties decrease as the scale of the study area and the number of affected and considered objects increases (Merz, 2006). Therefore, damage functions are especially suitable for studies on regional scales. Beside the structural vulnerability the temporal exposition or the probability of presence has to be considered additionally for mobile values such as vehicles.

In spite of the general methodological improvement in recent years (see e.g. http://www.floodsite.net/default.htm), most considerable progress in comparison of all risk components has been made in the field of hazard analyses whereas the methodological improvements concerning the estimation of the stock of elements and value and the development of structural vulnerability approaches are not equally progressed. This general statement concerning natural hazard risk analyses (see also Hollenstein, 2005) reflects the current situation in the framework of flood risk analyses (Koivumäki, 2010). Generally, it can be stated that risk-based natural hazard analyses, with their intrinsic complexities and inherent uncertainties, analyze the likely impacts and consequences under a very wide range of conditions (Hall and Solomatine, 2008) and assumptions. In a general risk analysis context Haimes (2009: p. 1653) asserts the following: "To the extent that risk analysis is precise and simple, it's not real. To the extent that risk analysis is real and complex: it's not precise."

Www.nat-hazards-earth-syst-sci.net/10/2451/2010/

\subsection{Flood risk analyses}

Concentrating on flood risk analyses, the most important hazard parameters/proxies in the framework of flood risk analyses are flood extents and water depths whereas further additional parameters are rarely considered (Merz, 2006; Meyer and Messner, 2007), Thereby, 1-D model approaches result solely in flood extent and water depth hazard maps, while the calculation of additional parameters depends on 2-D model approaches. 1-D based flood hazard analyses consist mainly of four steps: the data collection, a hydrologic part, a hydraulic part, and the pathway - inundation calculation (Panayotis et al., 2008). The main task of the first step is to generate (if not already existing) a Digital Elevation Model (DEM) or a Digital Terrain Model (DTM) (in the following DTM as a synonym) whereas ground truth survey data of the water body are ideally combined with an already existing DTM or laser scan data. The DTM poses the basis for the derivation of cross sections for water bodies. In the second step the frequency of the water discharges at gauges are analysed and, if necessary, discharges at ungauged locations are estimated by various regionalisation approaches. Thereby, statistical methods have to be distinguished from rainfall runoff models (see e.g. Panayotis et al., 2008). On the basis of the derived cross sections and the hydrological outputs the hydraulic dimensions can be calculated depending on the applied approach in a third step. The water level calculation can be realized either with 1-D or 2-D model approaches whereas 3-D model approaches are not applied so far (Panayotis et al., 2008). Beside these approaches so called 0-D or nonmodel approaches can be applied under certain specific situations (see therefor Woodhead et al., 2007). Depending on the model approach the calculation capabilities and output parameters vary. Generally, 1-D models can only assess water levels along the axis of water bodies whereas 2-D models can calculate additional hydraulic dimensions like flow depth, flow velocity, and others (see e.g. Panayotis et al., 2008). In this context, Pender et al. (2006) suggest that 1-D model approaches are more appropriate for floodplains which neither exceed three times the width of the river channel nor are separated from the channel by embankments. LAWA (2006) recommends that 1-D models can be a good choice in mountains and low mountain ranges when the stream flow takes mainly one direction whereas 2-D models should be used in plains or estuary areas and areas affected by tides. According to Panayotis et al. (2008), 1-D models are sufficient for the vast majority of water bodies, but are not satisfying when irregular flows occur. A more detailed overview of different models can be found e.g. in Woodhead et al. (2007) whereas Panayotis et al. (2008) discuss the categorization and characterization of different models. A comparative evaluation of different 1-D and 2-D models is discussed e.g. by Horritt and Bates (2002). Knebl et al. (2005) showed in a case study on regional scale that 1-D models tend to overestimate the hydrologic dimensions of flood events. In a last step, the 
flood extents and water depths can be calculated based on the results of 1-D hydraulic calculations. Therefore, the planar water levels, which are based on hydraulic calculations and assessed along the axis of water bodies, are subtracted from the DTM. Simple orthogonal extrapolations of these 1-D water levels to corresponding cross sections and further to flood plains can methodologically overestimate the extents of the resulting inundation areas and are problematic for meandering rivers. The overestimation results mainly from simple static extrapolations of planar water surfaces regardless of morphological or technical embankments. This however is a typical characteristic of Alpine floodplains. In contrast, 2-D models calculate the inundation area directly.

In the framework of regional risk analyses explicit flood hazard analyses are seldom realizable due to the high working and calculating costs. Therefore, the use of already existing inundation model results like the German ZÜRS (Zonierungssystem für Überschwemmung, Rückstau und Starkregen) (e.g. Kron and Thumerer, 2001) or the Austria HORA (HOchwasser Risikozonierung Austria) project (e.g. Blöschl et al., 2006; Willems, 2006) are practicable and pragmatic basics for integral risk analyses. However, according to the European Union (EU) directive on the assessment and management of flood risks within the Water Framework Directive (Council of the European Parliament, 2007) first flood hazard and risk maps must be implemented in the individual member states by 2013. Consequently, relative normalized hazard maps will be available as a basis for regional scale flood risk analyses in the future.

With reference to extreme flood event comprehensions, e.g. Kron and Thumerer (2001) or Kron and Willems (2002) understand 200 year return intervals as thresholds to define extreme events. Völkening and Odenhauser (2003) apply somehow a return period between 200 and 300 years for the estimation of the accumulated damage potential of extreme floodings in Germany but quote that further worst-case scenarios with return periods of 500 and more years are possible. Additionally, the possibility is always given that an event with lower probability of occurrence but higher magnitudes as the supposed extreme event occurs (Woo, 2002). The term extreme event may also be used for infrequent events which considerably exceed all historically observed water levels, and thus make existing protective measures ineffective. In such cases the probability of occurrence is so low, that it is impossible to quantify a frequency (ICPR, 2001: p. 2). A case study of Swiss Re and the Gebäudeversicherung Bern (GVB, 2001) applies return periods of more than 100 years as the basis for the estimation of Probable Maximum Losses.

It is very unlikely that an entire study area on regional or even national scale is affected by a single event (e.g. Kron and Thumerer, 2001; Kron 2001, 2004, 2005; Merz, 2006). Thus, e.g. reinsurance companies base their accumulation loss analyses upon predefined scenarios of the spatial affectedness of major loss events which are combined with hydraulic model outputs. These so-called accumulation loss zones consider meteorological parameters of synoptic patterns and hydrological circumstances like the location and size of catchment areas. In this context, e.g. Germany is divided into 8 accumulation loss zones which represent various spatial affectedness scenarios (see Kron, 2001, 2004; Kron and Thumerer, 2001; Kron and Willems, 2002; Munich Re, 2005). In general, it is necessary to consider and systematically evaluate magnitudes exceeding all documented historical events to cover potential extreme events (Bayer, 1980; Merz, 2006). Thereby, Merz (2006) describes methods of safety sciences and methods based on expert judgements to identify representative scenarios whereas most of the scenarios are not based on safety science methods but on (pragmatic) judgements of experts. In the future, more sophisticated stochastic Monte-Carlo based simulations of synthetic events (probabilistic modelling) should be developed and implemented (Munich Re, 2005) whereas at least a consortium of seven reinsurance companies and the Gesamtverband der Deutschen Versicherungswirtschaft (GDV, German Insurance Association) have developed such a probabilistic model based on 100 historic loss events in the meantime (Müller, 2009).

While estimating the potential loss consequences on the built environment, the water depth has the strongest influence on the amount of damage (Merz, 2006; Meyer and Messner, 2007), is internationally accepted as a flood magnitude proxy (Mayer and Messner, 2005; Merz, 2006) and is applied by water depth-damage relationships. A comprehensive literature review on flood related vulnerability concepts was published by Barroca et al. (2006). Generally, the correlation between water depths and assumed losses is described by regressions; except approaches which are based on intensity classes with step-growth damage values (e.g. BWG, 2006; Loat and Petraschek, 1997). According to Meyer and Messner (2007) there is no theoretical reason to prefer any functional form of regressions. Instead, especially the square root function, with water depth as the only parameter, is recommended by most of the existing research studies (e.g. IWK, 1999; BMLFUW, 2004; Merz, 2006; Messner and Meyer, 2007; Schmitke, 1995) and is at least plausible (Merz, 2006; Messner and Meyer, 2007) for approaches which integrate losses to buildings and inventory within one damage function. Linear regressions are appropriate for approaches, which distinguish losses to buildings and losses to inventory with separate damage functions (MURL, 2000; Bronstert, 2004). Based on detailed analysed risk indicators like buildings and inventory it is possible to correlate additional risk indicators with experiences from analysed events in the recent past. According to Meyer and Messner (2007) the 2002 Elbe event in Germany could somehow give a representative example as this event affected cities as well as rural areas and showed typical flood characteristics consisting both of plain river floods and flash floods at the tributaries. In retrospective the resulting direct, tangible losses in the Free State of Saxony can be proportionally subdivided 
into $62.5 \%$ to buildings and inventory, $36.2 \%$ to technical infrastructure, and $1.3 \%$ to agricultural products, whereas no significant proportional losses to vehicles are documented (Freistaat Sachsen, 2003). However, the process characteristics of flood events and the exposition of properties and infrastructure in pre-Alpine and moreover in Alpine regions are incomparable to those in the State of Saxony, Germany.

Event analyses from Switzerland (BAFU and WSL, 2007; Hilker et al., 2008) show at a first glance a related distribution of the general loss repartition throughout Switzerland at least for the 2005 event with approx. $75 \%$ private property losses and approx. 25\% public losses and losses to infrastructure, with a proportion of approx. $10 \%$ of the public/infrastructure sector in the most seriously affected cantons (Hilker et al., 2008). An overview of selected historical events shows that such proportions are very dependent on the event and region and vary between $17 \%$ private property and $83 \%$ public/infrastructure losses in August 1987 (cantons Uri, Valais, Ticino and Grisons) and 91\% private property and 9\% public/infrastructure losses in Canton Ticino in October 2000. In more detail, the private property losses of the event in 2005 can be subdivided into $52.4 \%$ content and inventory losses, $18.7 \%$ building losses, $15 \%$ damages due to business interruptions, $6.7 \%$ vehicle losses, and $7.1 \%$ other losses. The public losses and losses to infrastructure can be subdivided into $30 \%$ damages to hydraulic engineering structures, $23 \%$ road damages, $17.3 \%$ damages to forests, $14.1 \%$ agricultural damages, $10.7 \%$ damages to railway infrastructure, $2.6 \%$ water pollution abatement damages, and $2.3 \%$ others (BAFU and WSL, 2007). The losses inflicted by the flooding event of 2005 do not stem merely from river flooding but are a combination of flood, debris flow, and landslide processes (92\% flooding, ground water and mountain slope water, $3 \%$ debris flows, and 5\% landslides) (Hilker et al., 2008). Moreover, insurance loss data of the event in 2005 in Canton Berne show that more than $50 \%$ of the general affected buildings and $23 \%$ of the amount of losses can be localized in areas which are affected by landslides, ground water or mountain slope water (BAFU and WSL, 2007).

The event analysis of the 2005 event in Austria (BMLFUW, 2006; IWHW, 2006) shows that the overall proportion of the direct tangible losses in all affected provinces can be stated with $45.2 \%$ losses on infrastructure, $38.8 \%$ private property losses (at which damage to vehicles are nominal), and $16 \%$ losses to infrastructure of the Austrian Service for Torrent and Avalanche Control and the Austrian Flood Control (mainly of the Austrian Flood Control). Focusing in more detail on the study area of Tyrol, $54.4 \%$ losses are assigned to infrastructure, $33 \%$ to private property losses (buildings, contents and inventory), and $12.6 \%$ losses to technical measures of the control services. An itemised conclusion of the infrastructure sector shows that $39.4 \%$ are subjected to road damages, $21.1 \%$ to losses on community's properties (not precisely defined), $17.2 \%$ to infrastructure damages of the electrical power industry, $16.3 \%$ to railway damages, $3.1 \%$ to damages on structures of the sewerage maintenance, $2.1 \%$ to damages on telecommunication infrastructure, and $0.6 \%$ on damages on structures of the drinking water supply.

As discussed in the preceding paragraph, analysis approaches to estimate consequences to individuals are currently carried out unsatisfactory. This circumstance is also generally confirmed by Jonkman et al. (2008) and Jonkman and Vrijling (2008) whereas a very specific approach is presented to estimate the mortality under the specific restriction to flood events caused by the breaching of flood defence structures in low-lying areas of the Netherlands.

\section{Methods}

The hazard analysis presented in this study is based on results of the Austrian Flood Risk Zoning Project HORA. The data were provided by the Austrian Federal Ministry of Agriculture, Forestry, Environment and Water Management. While the hydraulic part of the HORA project is based on 1-D modelling and simple extrapolation procedures of the planar water surface, the resulting extrapolation errors in the floodplain were deleted in a first step (in the following revised HORA project) (see Sect. 3.1). Thereupon expert-knowledge-based accumulation loss zones were defined and spatially joined with the inundation areas of the hazard analysis, which results in five extreme event scenarios (see Sect. 3.2). In a third step, the elements at risk and corresponding damage potentials affected by (i) the inundation areas of the HORA project as well as the revised HORA project and (ii) the specific extreme event scenarios were identified. This exposure analysis is based on a geodatabase of the relevant stock of elements and values (see Sect. 3.3). In a last step, the losses of the five investigated extreme events (the so-called ESL) were estimated under consideration of different structural vulnerability approaches (see Sect. 3.4). A general overview on this brief introduced study framework is illustrated in Fig. 1.

\subsection{Hazard analysis}

In a general overview, the hydrologic part of the HORA project determines the discharge frequencies of the 30, 100, and 200 year statistical return periods (Blöschl et al., 2006). Thereby, the hydraulic project part contained the modelling of corresponding dimensional flows with a 1-D steady flow approach and the extrapolation of inundation dimensions by means of a simple planar water surface procedure (Willems, 2006). However, simple extrapolations of planar water surfaces have some limitations and especially inundation areas without any connection to flowing water bodies are still designated as hazard areas. To delete those areas an ArcGIS script was developed which briefly (i) reclassified the inundation rasters to consistent rasters with the raster value of one, thereupon (ii) the rasters with a unique value are converted 


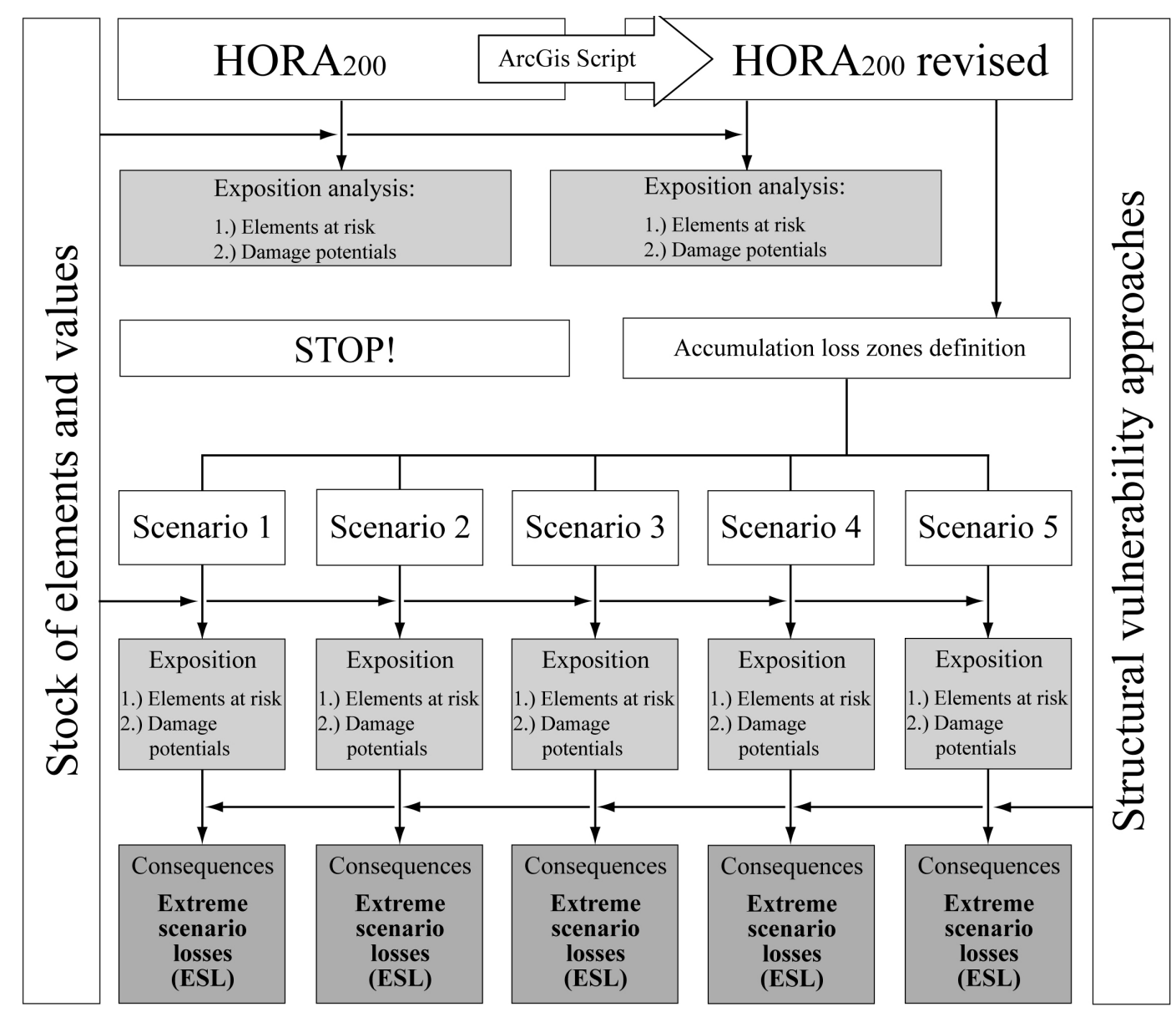

Fig. 1. Overview of the study concept: procedures (i) to analyse the exposures within the general HORA 200 flood hazard areas in Tyrol and (ii) to analyse the exposures and the consequences based on the defined extreme flood scenarios. The stock of elements and values forms the fundamental basis to identify exposed elements whereas the specific loss consequences are dependent on the applied structural vulnerability approaches.

to polygons, (iii) these polygons are spatially joined with the flood relevant axies of the water bodies, (iv) the identified polygons are selected, (v) the selected polygons are converted to rasters, and (vi) the resulting rasters are spatially joined with the originally inundation rasters. Thus, all inundation rasters without any connection to flowing water bodies are removed.

To correspond with the extreme event approach of the study the hydrologic return period of 200 years resulting from the HORA project and the, thereupon, calculated inundation areas and depths were considered. In this context, a general methodological restriction of the specific HORA project outcomes has to be mentioned for further analyses and interpretations. Beside the general trend of 1-D models to overestimate the inundation dimensions, the workflow of the specific model approach derives cross sections to represents the water body solely based on the DTM of the Bundesamt für Eich- und Vermessungswesen (BEV, Austrian Federal Office for Calibration and Measurement). The horizontal accuracy of this DTM with a raster width of $10 \mathrm{~m}$ is between $\pm 1-5 \mathrm{~m}$ for the HORA project relevant areas (http://www.bev.gv.at). Additional ground truth survey data were not considered, which means neither the profile of the river bed nor the structures of technical protective measures are explicitly implemented. Beside the relative low resolution of the DTM, the non-consideration of ground truth survey data has considerable implications on the volume representation of water bodies for hydraulic modelling. Moreover, protective measures of the river control in Austria are not explicitly integrated. Since the measures of the river control are designed for statistical reoccurrence intervals of 100 years this is not considered to be critical for at least the reoccurrence interval of 200 years. Adams et al. (2007) compared the accuracy of different terrain model sources (BEV $10 \mathrm{~m}$ DTM, $1 \mathrm{~m}$ DTM resulting from LiDAR data interpolations, and $1 \mathrm{mLiDAR}$ DTM including ground truth survey data) to represent the water body of the Inn River in the area of Innsbruck (province capital of the study area). Beside the obvious differences between the $10 \mathrm{mDTM}$ and the two $1 \mathrm{mDTMs}$ it can be shown that the mean volume difference 

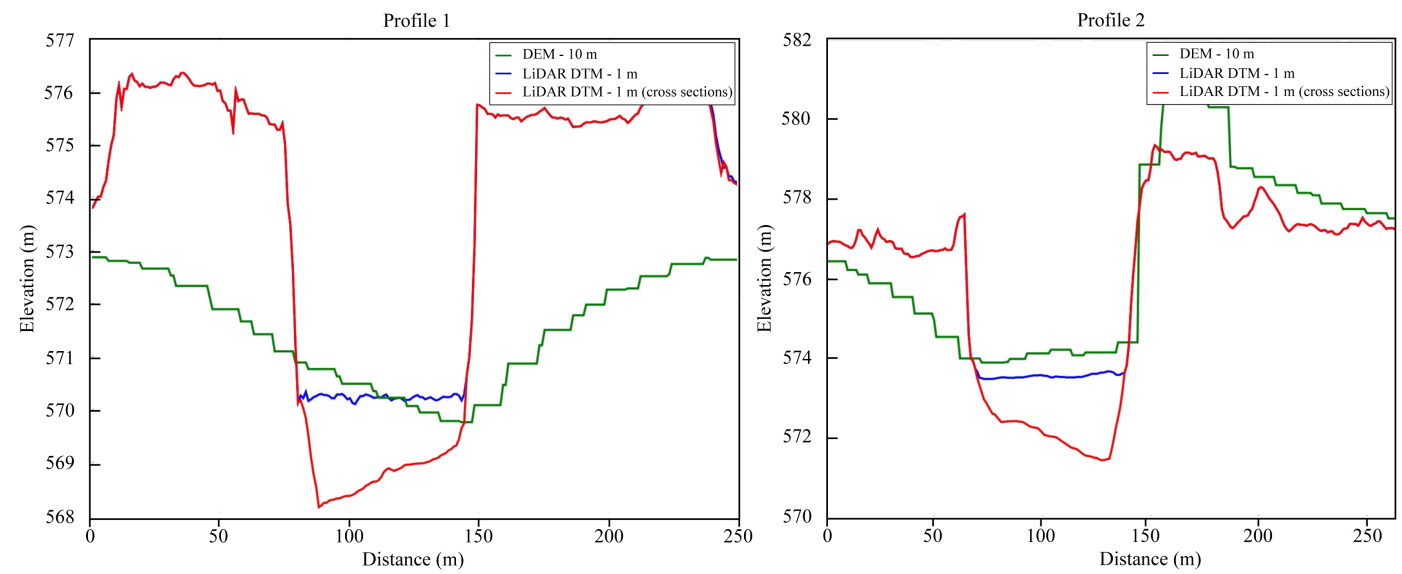

Fig. 2. Visualised differences between two exemplary cross-section representations in the municipal area of Innsbruck (province capital of Tyrol) to consider the water body of the Inn River for hydraulic model procedures. The demonstrated differences have a high influence on the model performance and are based on (i) the DTM of the Bundesamt für Eich- und Vermessungswesen (BEV) with a raster width of $10 \mathrm{~m}$ (DTM $-10 \mathrm{~m}$ ), (ii) a LiDAR data based DTM with a raster width of $1 \mathrm{~m}$ (LiDAR DTM $-1 \mathrm{~m})$, and (iii) a LiDAR data based DTM including ground truth survey data with a raster width of $1 \mathrm{~m}$ (LiDAR DTM - $1 \mathrm{~m}$ (cross section) (adapted and modified according to Adams et al., 2007).
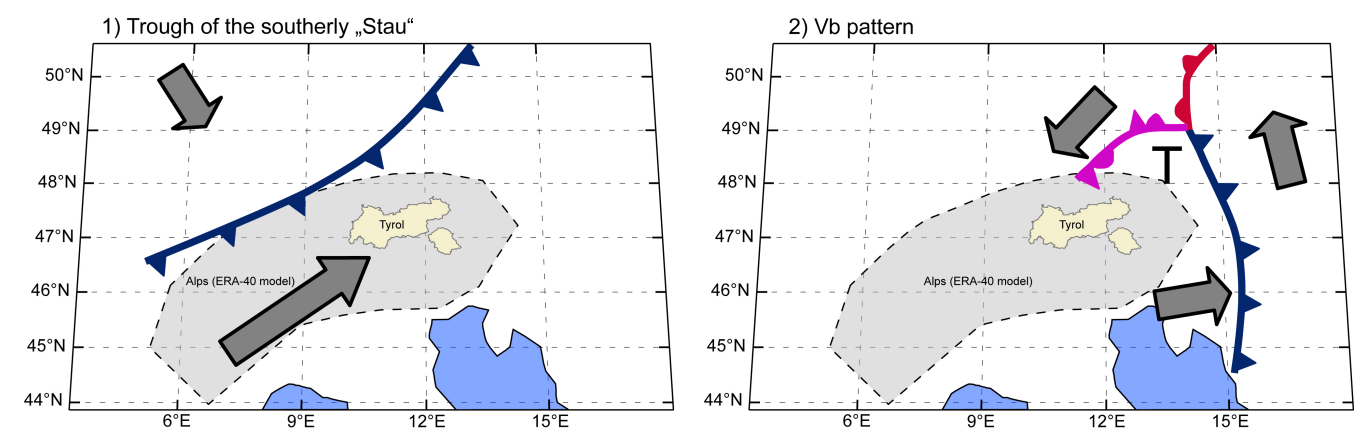

Fig. 3. Generalized synoptic patterns of (1) the trough of the "southerly Stau" and (2) the Vb pattern. The simple representation of the European Alps is based on the model of the Alps from the reanalysis project ERA-40 (adapted and modified according to Giardono, 2007).

of the derived cross section between the LiDAR data DTM and the LiDAR data DTM including integrated ground truth survey data can be stated with approx. $100 \mathrm{~m}^{3}$. Figure 2 illustrates this topic exemplarily on two profiles. These introduced topics have sustainable influences on the model results. It is impossible to quantify the influence in terms of probability, but as a consequence, the HORA results represent a return period of more than 200 years and, thus, the term extreme can be applied.

\subsection{Hazard scenarios}

Following the already introduced accumulation loss zones concept of reinsurance companies and the expert's judgement method to analysis scenarios, the extreme scenarios of the study are developed and defined in cooperation with five executive engineers (hydrology, hydraulic, civil engineering) and meteorologists of the regional council. Mainly typical synoptic patterns of heavy precipitation events and potential patterns of the spatial affectedness were systematically discussed and combined to five different affected zones of potential extreme scenarios. Beside the expert's individual knowledge, the analysis systematically considers synoptic patterns according to Seibert et al. (2007), topographic conditions (DTM and contour lines), catchment areas (database: Hydrographisches Zentralbüro), and historic event analyses (e.g. Blättler, 1995; BMLFUW, 2006; IWHW, 2006; Meier, 2002). Thereby, two different synoptic patterns are causally related with extreme flood events: southwest pattern with trough of the "southerly Stau" (terminology according to Seibert et al., 2007) and the so called Vb pattern. Moreover, northwestern patterns result in heavy precipitation events in the winter (e.g. destructive avalanche events in Austria, Switzerland and France in February 1999). Figure 3 gives a generalised synoptic overview of these two synoptic patterns which trigger extreme flood events. In order to obtain extreme flood scenarios, these defined accumulation loss zones were spatially joined to the revised inundation rasters of the HORA project. 


\subsection{Exposure analysis}

Concerning the risk indicator definition, the present flood risk study generally distinguishes between two layers: (i) buildings, contents and inventory (in the following inventory), vehicles, and individuals within the exposure analysis and (ii) buildings, inventory, and vehicles within the consequence analysis. This differentiation is mainly subjected to the already mentioned controversial discussion particularly in regard to ethic-moral concerns, the complexity, uncertainty, and ambiguity of human reactions, the non-existence of applicable approaches, and the study background with a particular focus on insured property losses and liability consequences. In order to analyse the exposure and the consequences adequately, the consistent and precise representation of the existing stock of elements and values plays a key factor and forms the basis for effective risk analyses. To consider the mentioned difference factors (see Sect. 2) adequately, a detailed geodatabase of the relevant stock of elements and values was established. The procedure results in a spatially precise database on an object-based property-byproperty level. Based on the background of the study the risk indicators of buildings, inventory, vehicles, and individuals were defined as relevant. Buildings and inventory were monetarily assessed on the basis of the replacement value and vehicles by their depreciated values. Furthermore, the mean sums insured by life insurance policies are applied to assess human lives. Especially the approach to apply the mean sums insured $b$ ylife insurance policies seems to be critical. However, this procedure follows the general study concept and the stakeholder's interests. The cooperation with the regional insurance market leader (Tiroler Versicherung) enables the estimation of representative mean insurance sums for the study area. The overall procedure, the methodological concept, and the analysis results have been recently published by Huttenlau and Stötter (2008). However, to ensure traceability and to introduce the procedure in a broader international context the main steps of the procedure are briefly discussed (see also Fig. 4):

- First, geocoded address-points and corresponding building layers, the land use planning, orthophotos (data source: Tyrolean Provincial Government Office), the digital land register, the DTM (data source: BEV), and additional basis layers were incorporated with statistic data (data source: Statistik Austria) in a consistent data structure (Fig. 4, Pre-processing of Geodata and Statistic data). To guarantee a consistent reference date of the sum covered by the insurance policies, the face values were index-linked on the basis of guidelines of the Austrian Insurance Association (VVO, 2007): contents insurances (inventory) and life insurances with the consumer-price index, building insurances with the building-cost index (data source: Statistik Austria), and a special decreasing line (KBX2) of the car leasing industry to determine the depreciated values for vehicles (Fig. 4, Pre-processing of insurance policies).

- In a second step, single insurance contracts were geocoded and statistically analysed, to estimate representative mean values. Thereby, the addresses of the single insurance polices were structurally and contently adapted and merged with the address-data set of the Tyrolean Provincial Government Office with an edited merge quote of over $92 \%$. In order for the historic, economic, and social disparities in Tyrol and their influence on the mean sum of insured buildings und inventory to be spatially considered, the study area was subdivided into different, relatively homogenous settlement regions (socio-economic units) (Fig. 4, Processing step Aggregation in socio-economic units). Within these regions and after a statistical portfolio analysis, validation, and correction, a further differentiation in six functional classes within the declared socio-economic units was implemented on the basis of the digital land register and the land use planning to incorporate the functional disparities of the single objects in detail. The sum insured for vehicles and life insurance policies were aggregated and analysed on a district level. As a result, representative mean insurance values for buildings, inventory, vehicles, and life insurances were statistically analysed (Fig. 4, Processing).

- Statistical data on households and the population on a community level as well as vehicles on a district level (data source: Statistik Austria) where segmented in an aliquot proportion over the address-points within the communities in a next step (with the exception, that no household and population data where applied within industrial and commercial areas). These localized and quantified elements were merged with the estimated mean insurance sums in a relational and systematic manner which results in a geodatabase of the stock of elements and values (Fig. 4, Post-Processing).

This property-by-property geodatabase enables an efficient analysis of the elements at risk, their corresponding damage potential, and the ESL within the framework of risk analyses (see also Fig. 1). Figure 7 shows an exemplarily visualised entity of the established geodatabase.

Within the exposure analysis the potentially affected elements (elements at risk) and their monetary values (damage potentials) are analysed. Thereby, the general endangered objects were identified first on the basis of the original inundation areas and second considering the revised inundation areas of the HORA. The scenario specific exposures were furthermore identified considering the inundation areas of the defined extreme scenarios. 


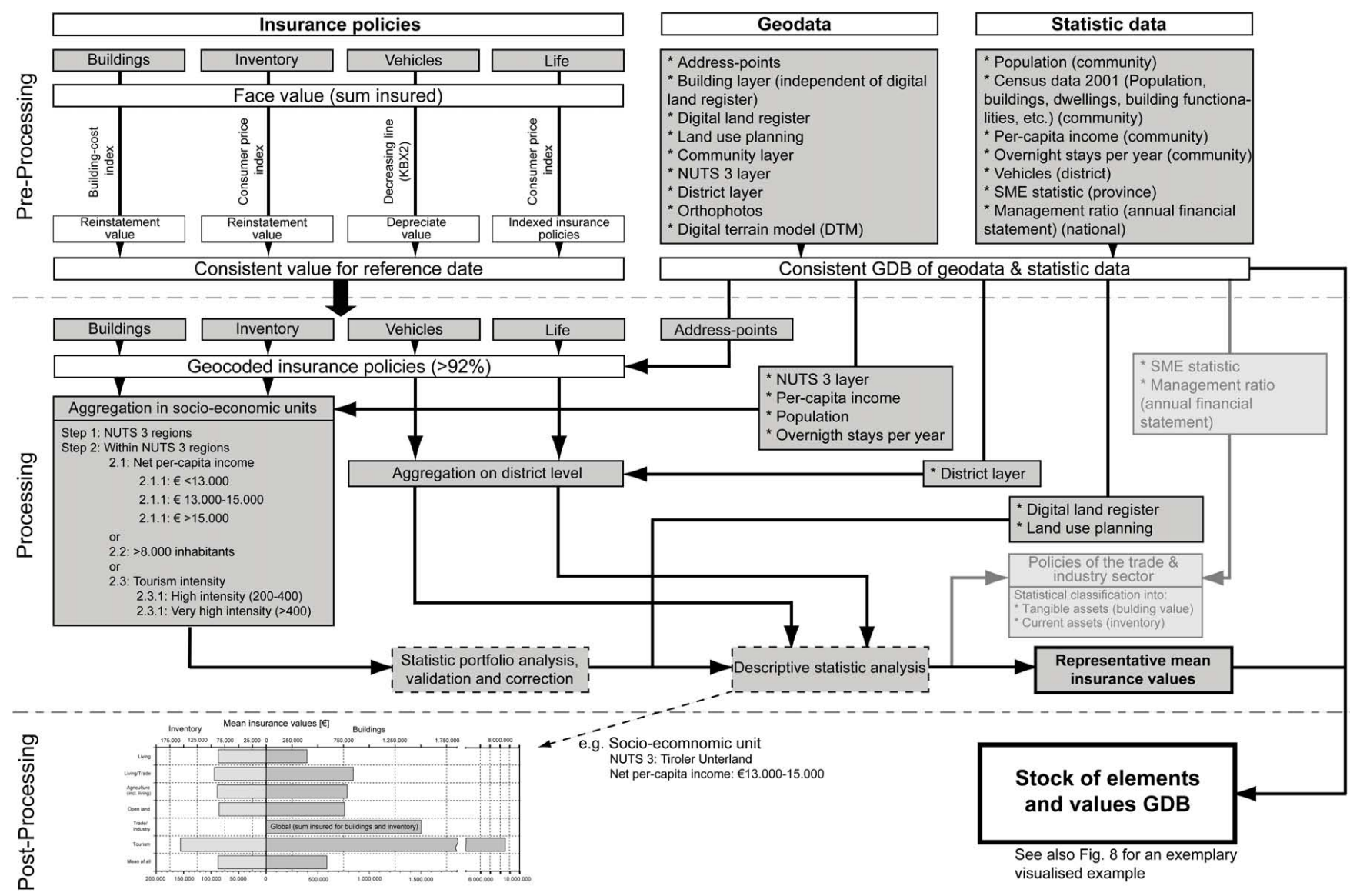

Fig. 4. Methodology, working steps, and combination towards a consistent geodatabase (GDB) of the stock of elements and values (the listed example of a socio-economic unit should only adumbrate the level of detail, for more details see Huttenlau and Stötter, 2008).

\subsection{Consequence analysis}

The consequence analysis aims at estimating the potential negative effects of the defined scenarios on the risk indicators under consideration. In contrast to the exposure analysis, individuals are not considered. By reference to the introduced methodological concepts it is obvious that a single ESL value may express a possible consequence under the considered specific assumptions. In order to highlight the linked consequences of different vulnerability approaches and to reflect the uncertainties of the approach in general, a range of potential ESL was estimated under consideration of different structural vulnerability approaches.

\subsubsection{Losses to buildings and inventory}

To consider the different functional characteristics of the individual elements at risk and the functional building classification within the applied vulnerability approaches, the individual damage functions and their specific functional differentiations were statistically adapted on a community-level (data source: Statistik Austria, 2004). As a result, statistically and functionally adapted damage functions were derived for all 279 municipalities considering the following vulnerability approaches:

- step growth absolute damage values (in the following BWG),

- linear relative damage function (in the following MURL),

- absolute damage functions (in the following TYROL).

\section{Step-growth absolute damage values}

The applied step-growth loss estimation considers three flood intensity classes and is based on the absolute damage function approach described by Loat and Petraschek (1997) and BWG (2006). Thereby, Swiss damage values for the reference year 1999 related to the three intensity classes (i) low (inundation depth up to $0.5 \mathrm{~m}$ ), (ii) medium $(0.5 \mathrm{~m}$ up to $2 \mathrm{~m}$ ), and (iii) high (greater than $2 \mathrm{~m}$ ) were converted into Euros (data source: Swiss National Bank), index-linked (data source: Statistik Austria), and finally adapted to the Austrian price level (data source: Eurostat). On the general basis of a constant segmentation of the total building values in Tyrol 

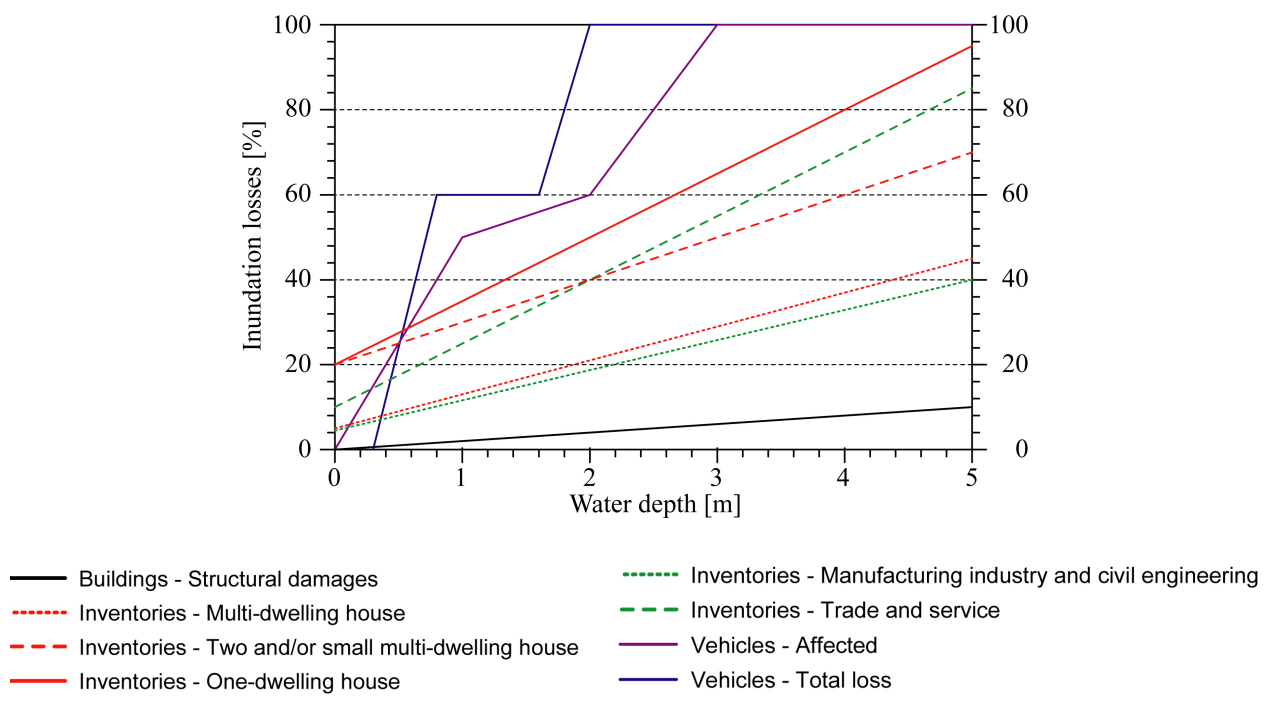

Fig. 5. Damage functions following the MURL concept (adapted according to MURL, 2000).

with $88 \%$ building and $12 \%$ inventory proportion (Huttenlau and Stötter, 2008), a weighted cross-sectional index of the building-cost index and the consumer-price index was ascertained and applied to adapt the damage values to the reference year 2006. Altogether, nine different damage categories of the briefly discussed approach have been considered and are adapted to six applied categories in the study area.

\section{Linear relative damage functions}

This approach is based on linear and relative damage functions of the MURL (2000) study which are developed (i) on the basis of analyses of the German flood database HOWAS (see e.g. IWK, 1999), (ii) by experiences from similar studies in other regions, and (iii) from surveys at specific sites within North Rhine-Westphalia (Germany). A specific characteristic of this approach is that losses to buildings are evaluated independently from losses to inventory with specific damage functions (see Fig. 5). Due to the integral insurance product for industry and commerce buildings, the stock of elements and values database do not explicitly distinguish between building und inventory values for those buildings. However, to correspond with the damage functions for the industry and commerce sector of this approach the listed values of industry and commerce buildings in the database were differentiated into tangible and current assets (see also Fig. 4). As $99.6 \%$ of the enterprises in the investigation area are small and medium-sized enterprises (SME), the applied constant proportion rule to distinguish between tangible and current assets is based on SME statistics. Therefore, SME statistics were analysed in Tyrol according to different enterprise sizes and their respective proportions (data source: Statistik Austria). Based on these contingents the weighted proportion between tangible and current assets for SME was assessed in general. Therefore, the management ratios of the annual financial statements in Austria (2002-2005) for these SME categories (data source: Austrian National Bank) was analysed and applied to the individual mean values of industry and commerce buildings within the database.

\section{Declining absolute damage functions}

After the serious flood event in August 2005 it was possible to estimate simple damage functions in Tyrol within this study. Thereby, about 700 concerned persons were contacted with a standardized questionnaire to estimate mean damage ratios for different building types and for vehicles whereas 145 suitable questionnaires where finally replied. The main criteria of the questionnaire refer to (i) water depth, (ii) flood type, (iii) functional type of the affected building, (iv) existence of a cellar, (v) oil contamination, (v) affected storeys, (vi) water depth within the affected storeys, (vii) resulting losses to buildings and inventory, (viii) losses to vehicles, and (ix) value of the affected assets. However, the value of the affected assets was often not completed validly and, thus, absolute instead of relative damage functions were derived. A square root function with one independent parameter (following the recommendation according to IWK, 1999; BMLFUW, 2004; Meyer and Messner, 2007; Schmitke, 1995) was applied to estimate the damage functions for buildings and individuals (subsuming both losses to buildings and losses to inventory) based on the relationship of the effective water depth and the occurred losses to buildings and inventory (see also Eq. 1).

$y=a \sqrt{x}$

$y=$ damage in Euro,

$a=$ specific value of the damage function, $x=$ water depth over top ground surface. 
In the process of the analysis procedure of the questionnaires detailed differentiated building categories were first analysed in detail under additional consideration of the subcategories oil contamination and the existence of cellars. To verify the derived regressions, the specific and common known influencing characteristics of oil contaminations or the explicit consideration of cellars on damage functions have been compared to already published data (Kreibisch et al., 2005a, b; Kron, 2004; Merz and Thieken, 2004; Müller and Thieken, 2005; Thieken et al., 2005). Despite the small sample size, the comparison shows that the data have corresponding and comparable characteristics. However, as a consequence of the relative small effective sample size, three general damage functions for residential buildings, buildings of the tourism industry, and buildings of the industry and commerce sector were finally derived in a second step and furthermore applied within the analysis (see Table 1).

\subsubsection{Losses to vehicles}

Four different vulnerability approaches to estimate potential vehicle losses were generally applied. In order to reflect the mobile character of vehicles, the (statistical) probability of presence has to be considered additionally. However, according to the non-linear and uncertain characteristics of the probability of presence of vehicles the assumptions are rough estimates:

- The first approach refers to the MURL (2000) study and is illustrated in Fig. 5 (in the following VA1 - for vehicle approach 1).

- The second approach is based on adapted relative damage categories of the flood damage database HOWAS and the MURL (2000) study. It is applied with an assumed probability of presence of $30 \%$ within different studies in Germany for the following flood magnitude categories: (i) $<0.5 \mathrm{~m}$, no damages; (ii) $0.5-$ $1.0 \mathrm{~m}, 20 \%$ damage ratio; (iii) $1.0-1.5 \mathrm{~m}, 40 \%$ damage ratio; (iv) $1.5-2.0 \mathrm{~m}, 50 \%$ damage ratio; and (v) $>2.0 \mathrm{~m}, 60 \%$ damage ratio (e.g. Emschergenossenschaft, 2004; Staatliches Umweltamt Minden, undisclosed; Staatliches Umweltamt Münster, 2004) (in the following VA2).

- Within the third approach (adapted from BMLFUW, 2009), all vehicles in inundation areas with water depth of more than $0.5 \mathrm{~m}$ are vulnerable with $50 \%$ while the probability of presence is assumed between $10 \%$ and $20 \%$ (in the following VA3).

- The fourth approach is based on the accomplished survey in the aftermath of the flood event in 2005 in Tyrol. Based on the small sample size of the category vehicles with 25 cases, a mean damage of EUR 10384 was derived and furthermore applied independently from the
Table 1. Absolute damage functions resulting from the survey after the flood event 2005 in Tyrol (TYROL approach).

\begin{tabular}{ll}
\hline Type of building & Regression \\
\hline Residential buildings & $y=10330 \times x^{0.5}$ \\
$\begin{array}{l}\text { Buildings of the hotel industry } \\
\text { Buildings of the industry and } \\
\text { commerce sector }\end{array}$ & $y=42070 \times x^{0.5}$ \\
\hline
\end{tabular}

effective water depth. The probability of presence was assumed to be $10 \%, 20 \%$, and $30 \%$ following the concepts of VA2 and VA3 (in the following VA4).

\section{Results}

\subsection{Hazard analysis and scenarios}

This pragmatic approach analyses potential scenarios in cooperation with regional experts from the respective regional councils. It results in five spatially differentiated extreme event scenarios which are spatially joined with the (revised) HORA inundation areas. These scenarios are illustrated in Fig. 6, whereas (i) scenario 1 results from a $\mathrm{Vb}$ pattern, (ii) scenario 2 to 4 result from different characteristics of southwest patterns ("southerly Stau"), and (iii) scenario 5 is based on a temporal succession of both first a $\mathrm{Vb}$ pattern which is immediately followed by a southwest pattern ("southerly Stau").

\subsection{Stock of elements and values}

The stock of elements and values was localized, quantified, and monetarily assessed on a property-by-property level. An exemplarily visualized extract for a single entity is illustrated in Fig. 7. On an aggregated level the following stock of elements and values were determined in Tyrol:

_ 700000 inhabitants result in an insured sum of approx. EUR 20 bn.,

- 447000 vehicles correspond to a depreciated value of approx. EUR 7 bn.,

- 168 000 buildings (including inventory) with analysed reinstatement values of approx. EUR $135 \mathrm{bn}$. These include approx. 161000 residential buildings or buildings with at least a residential function and corresponding values of approx. EUR 124 bn.

Table 2 gives an aggregated overview of the localized and quantified elements on a district level whereas Fig. 8 visualises the estimated values for the risk indicators of buildings and inventory in the study area aggregated on a community level and, additionally, lists the communities with the absolute highest value concentrations in a separate table. 
Table 2. The analysed and considered stock of elements and values aggregated on a district level for the risk categories of individuals, vehicles, and buildings (including inventory). The buildings results are classified for all addresses in general and for the addresses of residential buildings in Tyrol.

\begin{tabular}{|c|c|c|c|c|c|c|c|c|}
\hline \multirow[t]{2}{*}{ District } & \multirow{2}{*}{$\begin{array}{l}\text { Individuals } \\
\text { [count] }\end{array}$} & \multirow{2}{*}{$\begin{array}{l}\text { Individuals } \\
\text { [EUR bn.] }\end{array}$} & \multirow{2}{*}{$\begin{array}{l}\text { Vehicles } \\
\text { [count] }\end{array}$} & \multirow{2}{*}{$\begin{array}{l}\text { Vehicles } \\
\text { [EUR bn.] }\end{array}$} & \multicolumn{2}{|c|}{$\begin{array}{l}\text { Buildings in general } \\
\text { (buildings and inventory) }\end{array}$} & \multicolumn{2}{|c|}{$\begin{array}{l}\text { Residential buildings } \\
\text { buildings and inventory) }\end{array}$} \\
\hline & & & & & [count] & [EUR bn.] & [count] & [EUR bn.] \\
\hline Reutte & 31918 & 1.13 & 22735 & 0.38 & 9983 & 7.28 & 9655 & 6.64 \\
\hline Landeck & 45021 & 1.73 & 30410 & 0.55 & 11834 & 8.59 & 11325 & 7.78 \\
\hline Imst & 55096 & 1.74 & 38289 & 0.57 & 16076 & 10.87 & 15326 & 9.44 \\
\hline Innsbruck - Stadt & 116881 & 3.23 & 65044 & 1.06 & 12432 & 19.22 & 12140 & 19.03 \\
\hline Innsbruck - Land & 161341 & 5.44 & 104158 & 1.62 & 38498 & 26.78 & 37189 & 24.27 \\
\hline Schwaz & 77562 & 1.50 & 50915 & 0.82 & 19885 & 16.08 & 18949 & 14.59 \\
\hline Kufstein & 97773 & 2.16 & 62774 & 0.98 & 25753 & 19.34 & 24625 & 17.49 \\
\hline Kitzbühel & 61222 & 1.83 & 40633 & 0.65 & 20604 & 17.94 & 19719 & 16.81 \\
\hline Lienz & 50572 & 1.37 & 31907 & 0.55 & 12956 & 8.72 & 12334 & 7.70 \\
\hline Tyrol & 697386 & 20.13 & 446865 & 7.18 & 168021 & 134.82 & 161262 & 123.75 \\
\hline
\end{tabular}

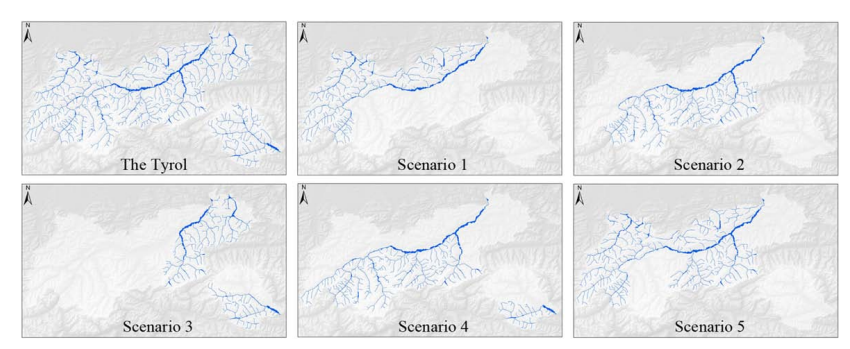

Fig. 6. Cartographic overview of the general flood hazard areas and the applied hazard scenarios in the study area Tyrol.

\subsection{Elements at risk and damage potentials}

Under consideration of the original HORA inundation data 110991 potential endangered individuals can be analysed in the entire study area. In contrast, the revised floodplains identify 105330 potentially endangered individuals. Focusing on the results of the revised inundation areas this represents a life insurance sum of EUR $2.92 \mathrm{bn}$. The scenario-specific mount of individuals at risk varies between 27409 (Scenario 3) and 86366 (Scenario 4) with corresponding cumulative live insurance sums between EUR $0.67 \mathrm{bn}$. and $2.38 \mathrm{bn}$. Concentrating on buildings and inventory, 20272 flood endangered buildings and 50157 dwellings with an accumulative value of EUR $19.99 \mathrm{bn}$. (thereof EUR 16.06 bn. for buildings and EUR $3.93 \mathrm{bn}$. for inventory) can be identified in the entire province of Tyrol (revised HORA areas). Depending on the scenario, the damage potentials range from EUR $6.02 \mathrm{bn}$. for Scenario 3 (thereof EUR $4.99 \mathrm{bn}$. for buildings and EUR $1.03 \mathrm{bn}$. for inventory) to $15.56 \mathrm{bn}$. for Scenario 5 (thereof EUR $12.38 \mathrm{bn}$. for buildings and EUR $3.18 \mathrm{bn}$. for inventory). Due to the heterogeneous land use patterns and the spatial as well as functional differences regarding the mean values of the elements

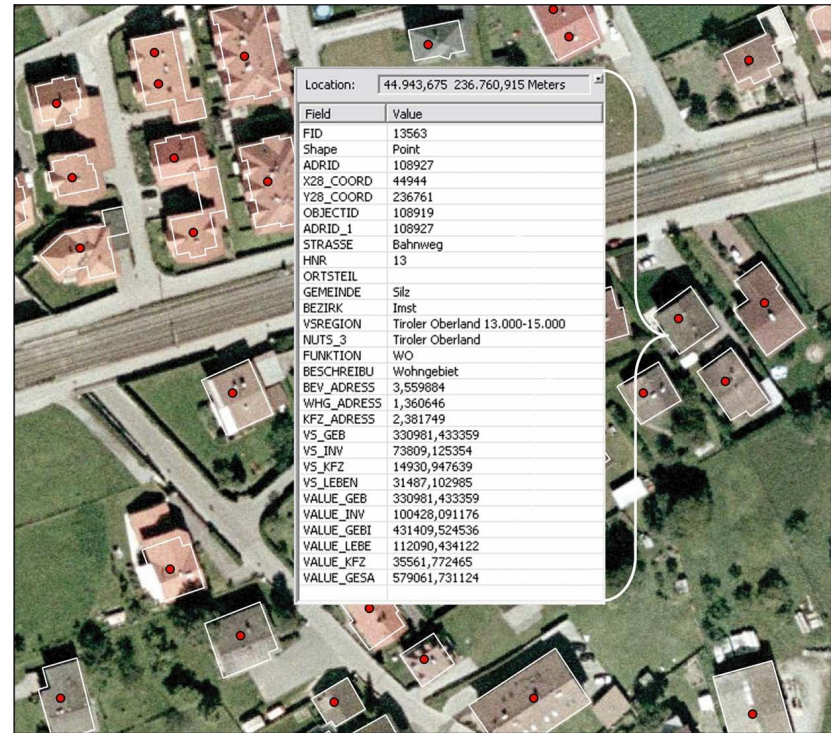

Fig. 7. Exemplary visualisation of the stock of elements and values for a single address point resulting from the property-by-property geodatabase. The table shows a summary of the most relevant information for the displayed object (e.g. VALUE_GEBI: building and inventory value of the presented object). More detailed information is saved in the geodatabase.

at risk, the highest damage potentials do not necessarily represent the highest quantity of elements at risk. The highest damage potentials for buildings and inventory can be stated with EUR 15.56 bn. for Scenario 5, whereas in contrast, the damage potentials for the scenario with the highest quantity of potentially affected buildings amounts to EUR $15.54 \mathrm{bn}$. (Scenario 4). Moreover, 62494 vehicles with a depreciated value of $1.00 \mathrm{bn}$. are located within the flood endangered areas. Depending on the individual scenario this means between 16966 (Scenario 3) and 50352 (Scenario 4) vehicles 


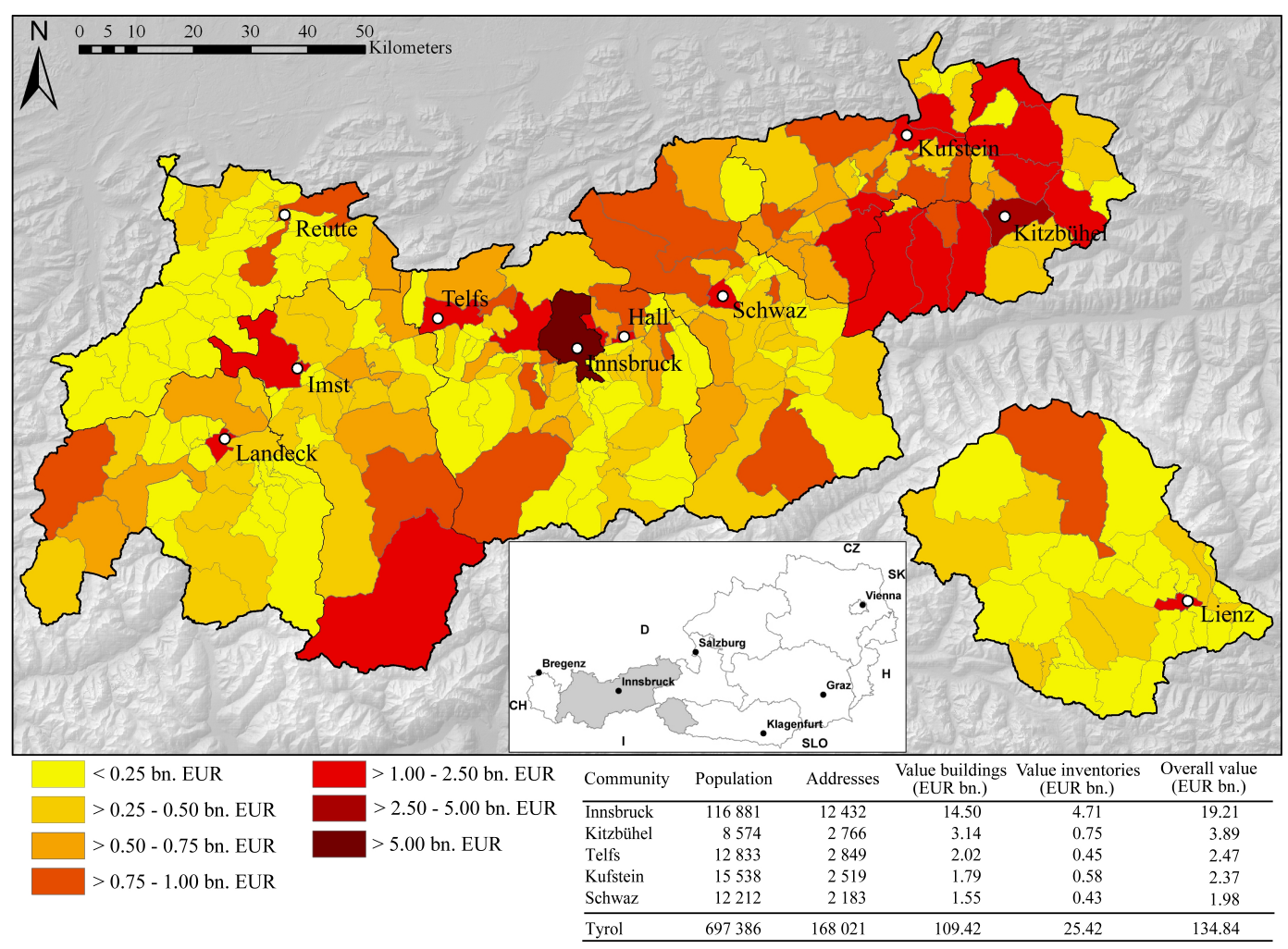

Fig. 8. Estimated stock of value for the risk indicators buildings and inventory in Tyrol on an aggregated community level. The table shows a ranking of the five communities with the highest concentration of values. The displayed municipalities are district capitals of the nine districts and additionally Telfs is mentioned due to the relatively high value concentration.

with the corresponding damage potentials. The spatial interaction of the process magnitude proxy water depth and the stock of elements and values, which presents the basic concept of flood risk analysis, is exemplarily illustrated in Fig. 9. The detailed results of the exposure analysis are listed in Table 3. Beside the general results, Table 3 demonstrates the difference between the original HORA inundation areas and the revised floodplains and their influence on the results. The percentage differences (on the basis of the number of elements at risk) are as follows: $6.7 \%$ for buildings, $5.1 \%$ for dwellings, $5.9 \%$ for vehicles, and $5.4 \%$ for individuals. The estimated damage potentials of the different scenarios are additionally depicted in Fig. 10.

\subsection{Extreme Scenario Losses (ESL)}

\subsubsection{Losses to buildings and inventory}

Based on the methods introduced in this study, the following ranges of potential ESL for the considered scenarios are estimated depending on the various discussed vulnerability approaches (additionally, Table 4 lists the results in more detail and a visualisation of the ESL ranges is given in Fig. 11):

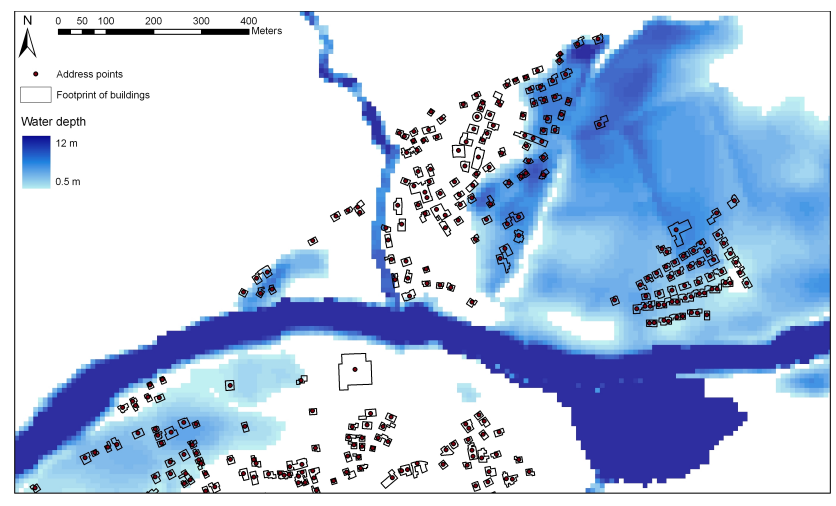

Fig. 9. Exemplary visualisation of the interaction between the water depth, resulting from the hazard analysis, and the stock of elements and values to identify the elements at risk, the damage potential, and to enable the evaluation of the ESL. The address points are linked to the geodatabase.

- Scenario 1: 12858 affected buildings and ESL between EUR 1.96 bn. (BWG), EUR 2.17 bn. (TYROL), and EUR 2.22 bn. (MURL).

- Scenario 2: 14070 affected buildings and ESL between EUR 2.09 bn. (BWG), EUR 2.37 bn. (MURL), and EUR 2.38 bn. (TYROL). 
Table 3. Elements at risk and damage potentials for the general hazard areas (original and adapted HORA flood areas) and the different considered scenarios.

\begin{tabular}{lrrrrrrr}
\hline & $\begin{array}{r}\text { HORA }- \\
\text { original }\end{array}$ & $\begin{array}{r}\text { HORA }- \\
\text { adapted }\end{array}$ & Scenario 1 & Scenario 2 & Scenario 3 & Scenario 4 & Scenario 5 \\
\hline n - buildings & 21623 & 20272 & 12858 & 14070 & 7339 & 14945 & 14671 \\
EUR (bn.) - buildings & 17.00 & 16.06 & 11.10 & 11.79 & 4.99 & 12.35 & 12.38 \\
n - dwellings & 52721 & 50157 & 37814 & 40343 & 1914 & 41500 & 41299 \\
EUR (bn.) - inventory & 4.14 & 3.93 & 2.89 & 3.10 & 1.03 & 3.19 & 3.18 \\
EUR (bn.) - buildings and inventory & 21.14 & 19.99 & 13.99 & 14.89 & 6.02 & 15.54 & 15.56 \\
n - vehicles & 66186 & 62494 & 44372 & 48190 & 16966 & 50352 & 49807 \\
EUR (bn.) - vehicles & 1.06 & 1.00 & 0.71 & 0.77 & 0.27 & 0.81 & 0.80 \\
n - individuals & 110991 & 105330 & 77183 & 83197 & 27409 & 86366 & 84994 \\
EUR (bn.) - individuals & 3.08 & 2.92 & 2.13 & 2.29 & 0.67 & 2.38 & 2.33 \\
EUR (bn.) - total amount & 25.28 & 23.91 & 16.83 & 17.94 & 6.96 & 18.732 & 18.69 \\
\hline
\end{tabular}

Table 4. Number of affected addresses and ESL under consideration of the different applied approaches and scenarios. The mean ESL based on the applied approaches is additionally listed.

\begin{tabular}{|c|c|c|c|c|c|c|}
\hline & & Scenario 1 & Scenario 2 & Scenario 3 & Scenario 4 & Scenario 5 \\
\hline \multicolumn{2}{|c|}{ Affected addresses (n) } & 12858 & 14070 & 7339 & 14945 & 14671 \\
\hline \multirow{6}{*}{ 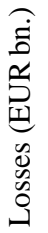 } & BWG & 1.96 & 2.09 & 0.89 & 2.20 & 2.17 \\
\hline & MURL - buildings & 0.46 & 0.49 & 0.20 & 0.51 & 0.51 \\
\hline & MURL - inventory & 1.76 & 1.88 & 0.73 & 1.96 & 1.94 \\
\hline & MURL - total & 2.22 & 2.37 & 0.93 & 2.47 & 2.45 \\
\hline & TYROL & 2.17 & 2.38 & 1.25 & 2.54 & 2.48 \\
\hline & Mean & 2.12 & 2.28 & 1.02 & 2.40 & 2.37 \\
\hline
\end{tabular}

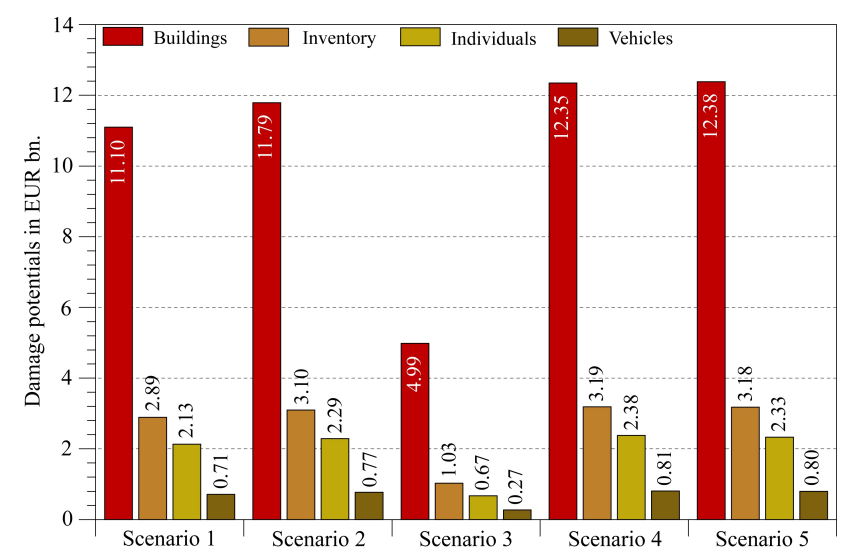

Fig. 10. Damage potentials of the different scenarios in bn. EUR. The inventory of the industry and commerce sector is included into the category of buildings (unlike the demonstration for the ESL in Table 4).

- Scenario 3: 7339 affected buildings and ESL between EUR 0.89 bn. (BWG), EUR 0.93 bn. (MURL), and EUR 1.25 bn. (TYROL).

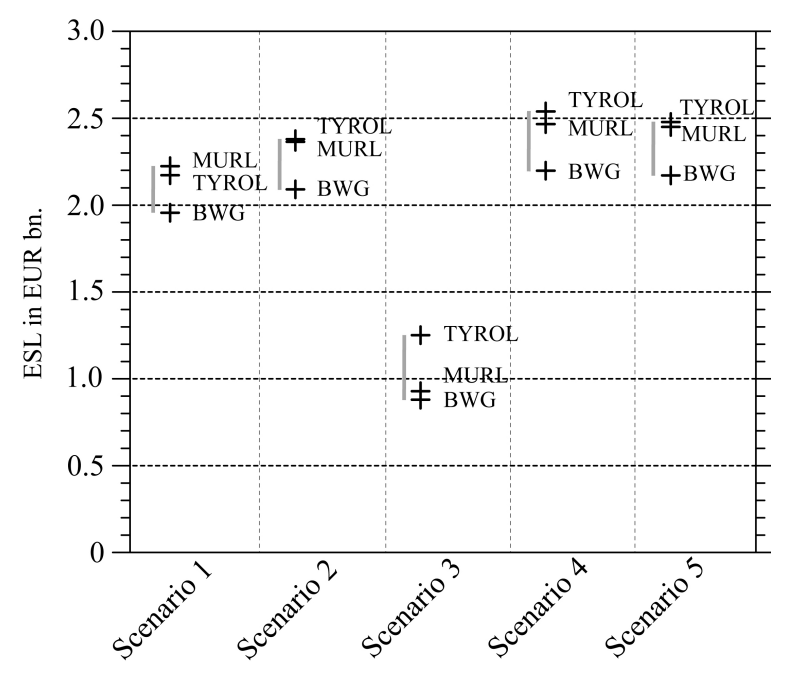

Fig. 11. Range of the analysed ESL for buildings and inventory according to the different applied approaches BWG, MURL, and TYROL in EUR bn.

- Scenario 4: 14945 affected buildings and ESL between EUR 2.20 bn. (BWG), EUR 2.47 bn. (MURL), and EUR 2.54 bn. (TYROL).

www.nat-hazards-earth-syst-sci.net/10/2451/2010/ 
Table 5. Overview of estimated ESL to vehicles for Scenario 1, dependent upon the different approaches applied.

\begin{tabular}{lcrr}
\hline Approach & $\begin{array}{c}\text { Probability } \\
\text { of presence }\end{array}$ & $\begin{array}{r}\mathrm{n}-\text { affected } \\
\text { vehicles }\end{array}$ & $\begin{array}{r}\text { Losses } \\
\text { [EUR mill.] }\end{array}$ \\
\hline VA1 & $\begin{array}{c}\text { Dependent upon } \\
\text { water depth }\end{array}$ & 34396 & 544 \\
VA2 & $30.0 \%$ & 13312 & 126 \\
VA3 & $10.0 \%$ & 4413 & 35 \\
VA3 & $12.5 \%$ & 5516 & 44 \\
VA3 & $15.0 \%$ & 6620 & 53 \\
VA3 & $17.5 \%$ & 7723 & 62 \\
VA3 & $20.0 \%$ & 8826 & 71 \\
VA4 & $10.0 \%$ & 4413 & 46 \\
VA4 & $20.0 \%$ & 8826 & 92 \\
VA4 & $30.0 \%$ & 13312 & 138 \\
\hline
\end{tabular}

- Scenario 5: 14671 affected buildings and ESL between EUR 2.17 bn. (BWG), EUR 2.45 bn. (MURL), and EUR 2.48 bn. (TYROL).

In a brief summary, the BWG approach estimates scenariospecific losses between EUR 0.89bn. (Scenario 3) and EUR 2.20 bn. (Scenario 4), the results based on the MURL approach vary between EUR $0.93 \mathrm{bn}$. (Scenario 3) and EUR 2.47 bn. (Scenario 4), whereas the results based on the survey in Tyrol can be stated between EUR 1.25 bn. (Scenario 3 ) and 2.54 bn. (Scenario 4).

\subsubsection{Losses to vehicles}

Comparing the estimated ESL to vehicles, the results on the basis of VA1 are significantly higher than those of the other considered approaches (between a factor of 3.9 and 15.5 for the example of Scenario 1). This characteristic is obvious and systematic and can be seen through all the considered scenarios. Due to the high deviations in the results of VA1 in comparison to the other approaches applied (see also Table 5) VA1 is excluded and thus not considered furthermore. This is supported by the fact that VA2 is partially enhanced in VA1, and the circumstance that this approach is not further applied within other studies (in comparison to the building and inventory damage functions of the MURL study). Regardless of VA1, the analysed losses still vary greatly depending on the applied vulnerability approach. For example, the losses of Scenario 1 vary between EUR 35-138 mill., whereas under consideration of VA3 the lowest and under consideration of VA4 the highest losses are analysed. These absolute results are declared independent of the approach-specific assumed probability of presence. However, the probability of presence has a very strong influence on the results and is responsible for the distinct wide range of the estimated results. In this context, the results of VA3 vary between EUR 35 mill.
Table 6. Overview of estimated ESL to vehicles for the different scenarios applied.

\begin{tabular}{|c|c|c|c|c|}
\hline & Scenario & $\begin{array}{l}\text { Probability } \\
\text { of presence }\end{array}$ & $\begin{array}{r}\mathrm{n}-\text { affected } \\
\text { vehicles }\end{array}$ & $\begin{array}{r}\text { Losses } \\
\text { [EUR mill.] }\end{array}$ \\
\hline \multirow{5}{*}{$\underset{⿱}{>}$} & Scenario 1 & \multirow{5}{*}{$30 \%$} & 13312 & 126 \\
\hline & Scenario 2 & & 14457 & 136 \\
\hline & Scenario 3 & & 5090 & 48 \\
\hline & Scenario 4 & & 15106 & 143 \\
\hline & Scenario 5 & & 14942 & 141 \\
\hline \multirow{5}{*}{$\stackrel{n}{>}$} & Scenario 1 & \multirow{5}{*}{$10 \%$} & 4413 & 35 \\
\hline & Scenario 2 & & 4787 & 38 \\
\hline & Scenario 3 & & 1690 & 14 \\
\hline & Scenario 4 & & 5001 & 40 \\
\hline & Scenario 5 & & 4945 & 40 \\
\hline \multirow{5}{*}{$\sum_{>}^{m}$} & Scenario 1 & \multirow{5}{*}{$20 \%$} & 8826 & 71 \\
\hline & Scenario 2 & & 9574 & 77 \\
\hline & Scenario 3 & & 3379 & 27 \\
\hline & Scenario 4 & & 10003 & 80 \\
\hline & Scenario 5 & & 9890 & 79 \\
\hline \multirow{5}{*}{$\underset{⿱}{\lessgtr}$} & Scenario 1 & \multirow{5}{*}{$10 \%$} & 4413 & 46 \\
\hline & Scenario 2 & & 4787 & 49 \\
\hline & Scenario 3 & & 1690 & 18 \\
\hline & Scenario 4 & & 5001 & 52 \\
\hline & Scenario 5 & & 4945 & 51 \\
\hline \multirow{5}{*}{$\underset{\lessgtr}{\triangleright}$} & Scenario 1 & \multirow{5}{*}{$30 \%$} & 13312 & 138 \\
\hline & Scenario 2 & & 14457 & 149 \\
\hline & Scenario 3 & & 5090 & 53 \\
\hline & Scenario 4 & & 15106 & 156 \\
\hline & Scenario 5 & & 14942 & 154 \\
\hline
\end{tabular}

(probability of presence of 10\%) and EUR 71 mill. (probability of presence of 20\%), whereas the results of VA4 vary between EUR 46 mill. (probability of presence of 10\%) and EUR 138 mill. (probability of presence of 30\%). Depending on the considered approach and the probability of presence assumption, the estimated losses vary between EUR 35138 mill. for Scenario 1, EUR 38-149 mill. for Scenario 2, EUR 14-53 mill. for Scenario 3, EUR 40-156 mill. for Scenario 4, and EUR 40-154 mill. for Scenario 5. An overview on the estimated results for the different scenarios is listed in Table 6.

\section{Discussion}

Based on revised inundation areas of the HORA project and defined extreme flood scenarios this study focuses on the estimation of the elements at risk, their corresponding damage potentials, and the ESL in the Federal Province of Tyrol. The interaction between scenario dependent flood areas and the detailed geodatabase of the stock of elements and values allows the quantification of the corresponding elements at risk and their immanent damage potentials. A further consideration of the specific susceptibilities of the elements 
at risk to the water-depth enables the estimation of the ESL for different flood scenarios.

A comparative analysis of the applied vulnerability approaches for buildings and inventory shows that the BWG approach generally determines the lowest losses. In contrast, maximum loss values result from the damage functions developed after the flood 2005 in Tyrol, except Scenario 1 with the highest losses related to the water-depth-damage relationships According to the MURL approach.

The percentage differences between the lowest (resulting from the BWG approach) and the highest (generally resulting from the TYROL approach) ESL can be ascertained with $13.7 \%$ for Scenario 1, $13.8 \%$ for Scenario 2, $42.3 \%$ for Scenario 3, $15.5 \%$ for Scenario 4, and $14.2 \%$ for Scenario 5 . When focusing on the differences between the BWG and the MURL approach the following deviations can be stated with $13.7 \%$ for Scenario 1, $13.1 \%$ for Scenario 2, 5.6\% for Scenario 3, $12.2 \%$ for Scenario 4, and $12.9 \%$ for Scenario 5 . When comparing the BWG and the MURL approach, and the general tendency of the TYROL approach to higher loss estimations, as in Scenario 3, the following explanations can be found for the outliers: (i) the damage functions themselves, (ii) the process dynamics and the therewith correlated consequences in the Alpine environment, and (iii) the specific land use patterns within the five scenario areas. As the damage functions of the TYROL approach are based on a rather small sample size, they are not statistically firm and thus the applied functions allow only simple differentiations of the object's functionalities. Moreover, the damage data of the flooding event 2005 originates mainly from the western part of Tyrol whereas especially Scenario 3 is located in the eastern part with both a significant different morphologic situation and different land use patterns. Because of the lack of detailed information on the origin of the other applied damage functions, a clear and comparative statement and assessment concerning the applied approaches is not possible. Nevertheless, the specific process dynamics in inner Alpine and especially in central Alpine environments - in comparison with pre- or non-Alpine regions - seem to affect the vulnerability significantly. On a more detailed community level, the results show that in the Central Alps these specific uncertainties, expressed through the range of the results, seem to be higher than in other regions. Furthermore, the range of the results is wider in (sub-)urban and narrower in rural settlements. Hence, the quantification of flood consequences with the common vulnerability approaches is more uncertain in more complex (sub-)urban land use patterns as well as in the Central Alps. Generally, the ranges of the analysed results indicate the inherent uncertainties of the applied approaches.

In contrast to the estimation of the damage potentials (maximum values for Scenario 5) but analogue to the analysis of the elements at risk, the highest ESL are estimated between EUR 2.20-2.54 bn. (Scenario 4). This can somehow be explained by the peculiarity that the highest amount of affected buildings but not the highest monetary value can be identified for Scenario 4. Hence, more buildings with a fractionally lower damage potential in total (resulting from a generally lower mean value of the single objects) lead to higher ESL independent of the general differentiation between absolute and relative damage functions. Moreover, the marginal differences of the damage potentials between Scenarios 4 and 5 in detail show that the higher damage potential values for Scenario 5 are solely subjected to the risk indicator of buildings whereas the higher values for the risk indicator of inventory can be stated for Scenario 4. Due to the fact, that on the basis of the MURL approach the losses predominantly result from losses on inventory, the ESL of this specific relative vulnerability approach are primarily dependent on inventory and secondarily on building parameters. Beside these circumstances the scenario-specific characteristics of the flooding depths distribution on affected elements as well as the specific spatial distribution and functional differentiation of those elements (with regard to the structural vulnerability) affect the results considerably.

IWK (1999) already mentioned the systematic problems and uncertainties when applying empirical damage functions and recommended the definition of synthetic damage functions in the framework of loss estimation procedures for buildings and inventory. Penning-Rowsell et al. (2003) have introduced such synthetically generated damage functions in England whereas during the period of this investigation, no adequate data existed for the study area. Meanwhile, first experiences with synthetic damage functions were gained for a cost-benefit analysis in Greifswald (Germany) (Buck et al., 2008) and Koivumäki et al. (2010) discuss that the synthetic damage functions seems to be more valuable than empirical approaches. However, the adequate generation of synthetic damage functions is very labour, time, and cost intensive and, when transferring damage functions to other areas, additional uncertainties are inherent to such damage functions, too. In order to improve the flood risk analysis methodology, endeavours of further development should be undertaken to generate more robust, regional and functionally differentiated damage functions; both empirically and synthetically. The HOWAS 21 database (interactive flood loss pool with the possibility to generate project specific damage functions, e.g. Thieken et al., 2010) at the GeoForschungsZentrum (GFZ) in Potsdam (Germany) will probably improve this situation. Therefore, beside the improvement of flood risk analysis capabilities in general, further investigation should be undertaken to establish specific empirical and synthetical damage functions for Alpine regions, especially against the background of spatially more detailed applications.

The estimation of possible vehicle losses is based on simple approaches and assumptions. Thereby, the results show very wide ranges depending on the applied approaches and the need to be interpreted carefully. Beside the specific damage functions for the risk indicators of vehicles the probability of presence is hard to determine and, thus, has strong influences on the estimated results. In comparison, the 
considered assumptions of the probability of presence have a higher weighted influence on the results than the specific damage functions themselves. Nevertheless, this risk indicator of vehicles has to be considered and discussed in studies with an insurance background, as shown in this study (e.g. due to the proportion of the risk indicator of vehicles within the specific insurance portfolio). However, it is necessary to keep in mind that flood losses to vehicles might be comparably low. Beside the specific flood characteristics, the losses are highly dependent on human reactions. For example, no significant losses to vehicles were quoted during the Elbe flood event in 2002 (see Meyer and Messner, 2007; Freistaat Sachsen, 2002) or the 2005 event in Austria (BMLFUW, 2006).

The estimation of consequences to humans is highly interconnected with the individual reaction to the specific extreme situation and, therefore, hardly to quantify. Moreover, this topic is very controversially discussed and the complexity, uncertainty, and ambiguity of the probability of presence as well as human reactions in extreme situations are hard to quantify. For this reason, the study focuses on the determination of the exposure of individuals in general and the monetary quantification on the basis of mean life insurance sums.

\section{Conclusions}

The present study estimates fundamental quantitative information on (i) the general endangerment of buildings, inventory, vehicles, and individuals and (ii) scenario-specific exposures and consequences of potential extreme flooding scenarios in the province of Tyrol. Thereby, 20272 buildings, 50157 dwellings, 62494 vehicles, and 105330 individuals were generally identified in flood endangered areas according to the (revised) HORA inundation map with a 200 year reoccurrence interval. This means in a reverse conclusion that $12 \%$ of the buildings, $16 \%$ of the dwellings, $14 \%$ of the vehicles, and $15 \%$ of the individuals are located in flood endangered areas. Focusing on the corresponding damage potential the assessed monetary values of these elements at risk can be stated with approx. EUR $20 \mathrm{bn}$. for buildings and inventory, EUR 1 bn. for vehicles, and EUR 2.9 bn. for individuals. The further analysis of potential losses of extreme scenarios shows that extreme events can result in losses up to approx. EUR 2.5 bn. (Scenarios 4 and 5) solely on buildings and inventory (property losses). The correlation of the potential buildings and inventory losses of EUR $2.5 \mathrm{bn}$. with the findings of the 2005 event analysis especially for Tyrol (BMLFUW, 2006) estimates further losses of EUR $1 \mathrm{bn}$. to infrastructure of the control services (Austrian Torrent and Avalanche Control and Austrian Flood Control) and of EUR $4.1 \mathrm{bn}$. to infrastructure in general. The further proportional distribution of the direct tangible damages lists the consequences as follows: damages and losses of approx. EUR $2.5 \mathrm{bn}$. to buildings and infras- tructure, EUR $1.63 \mathrm{bn}$. to streets, EUR 870 mill. on structures of the Austrian Flood Control, EUR 870 mill. to specific community property, EUR 700 mill. to infrastructure of the electrical power industry, EUR 670 mill. to the railway network, EUR 130 mill. to the sewage disposal, EUR 90 mill. to telecommunication structures, and EUR 20 mill. to structures of the drinking water supply. Summarized, the direct tangible losses of extreme flood scenarios in Tyrol can reach cumulative loss amounts up to EUR 7.6 bn. However, it must be clearly noticed that such relationships can be interpreted as rough estimations due to the singularity of every event and the non-linear comparative loss increase of the different indicators. From a holistic point of view it is acknowledged that beside the considered risk indicators the overall losses are considerably dependent on the direct intangible category loss of lives, psychological consequences and stress, and indirect damages in general (Merz, 2006). Thereby, direct intangible damages and indirect damages can cause an important or even dominant part of the overall flood losses (FEMA, 1998; Penning-Rowsell and Green, 2000b).

The present study discusses comparatively different vulnerability approaches to quantify possible consequences of extreme flooding events. As a main general conclusion it can be stated that homogenous, adequate, and representative analyses of the stock of elements and values represent a key factor for effective natural hazard risk analyses and the comparability of consequences of different hazard processes (multi-risk analyses). The relative minor range of the results (at least for the risk indicators of buildings and inventory) estimated with absolute and relative vulnerability approaches - highlights this. Furthermore, flood loss liabilities and the individual consequences on the market can be identified as further key issues with major implications to society. In this context, losses which are not covered by insurance companies and thus have to be paid by the individuals, flood liability consequences for the insurance sector, and public options for action concerning regulation instruments like national catastrophe funds or alternative risk transfer mechanisms have to be differentiated and addressed.

Beside the improvement of adequate damage functions further future research activities in the framework of regional accumulative risk analyses could incorporate probabilistic methods to generate synthetic event datasets (initiated by statistical analyses of historic events) and thereupon arranged stochastic loss evaluation procedures based on flood maps of the EU directive on the assessment and management of flood risks (Council of the European Parliament, 2007).

Beside the insurance industry, the results are addressed and (meanwhile) considered as decision support information for decision makers in the administration, the politic, and the emergency management of the civil protection in the Federal Province of Tyrol. Especially for the insurance industry and under reference to the upcoming EU-wide regulatory requirements on capital adequacy and risk management (Solvency 2 directive) such scenario-based ESL analyses can 
define an upper limit of possible losses under worst-case aspects (Probable Maximum Losses), which has additionally supplemented with detailed probabilistic methods and stochastic assessment methods.

The scale dependent accuracy and the related uncertainties of such studies set limits to the interpretations of results. The assertions made in this context are suitable for accumulated loss analyses but are methodologically unsuitable for more spatially detailed conclusions on the individual objects scale.

Acknowledgements. This paper originated as part of a multi-risk project at alpS - Center for Natural Hazard and Risk Management (Innsbruck, Austria) in cooperation with both the Institute of Geography and the Institute of Public Finance (University of Innsbruck, Austria), the Tiroler Versicherung (Tyrolean Insurance Company) (Innsbruck, Austria), and the Federal Water Engineering Administration in the Federal Ministry of Agriculture, Forestry, Environment and Water Management (Vienna, Austria). The required basis data were provided by the Tyrolean Provincial Government Office and Statistik Austria. Andrew Moran is gratefully acknowledged for final editing.

The authors wishes to thanks the reviewers for their effort and constructive comments.

Edited by: T. Glade

Reviewed by: M. Keiler and A. Assmann

\section{References}

Amt der Tiroler Landesregierung (Ed.): Statistisches Handbuch für Tirol 2009, 2009.

Adams, M., Falkner, M., Franke, M., Jochem, A., Lochner, B., Link, S., Vetter, M., and Werthmann, M.: Hochwasser Risiko Modellierung Innsbruck, Endbericht zum Projektmodul Geoökologie und Raumforschung, Institut für Geographie, Universität Innsbruck, available at: http://www.uibk.ac.at/geographie/personal/vetter/artikel/ adams_et_al_2007_techrep_schadenspot.pdf (last access: 6 October 2010), 2007 (in German).

BAFU (Bundesamt für Umwelt) and WSL (Eidgenössische Forschungsanstalt für Wald, Schnee und Landschaften) (Ed.): Ereignisanalyse Hochwasser 2005, Teil 1 - Prozesse Schäden und erste Einordnung, 2007 (in German).

Banse, G. and Bechmann, G.: Interdisziplinäre Risikoforschung, Eine Bibliographie, Westdeutscher Verlag GmbH, 1998 (in German).

Barroca, B., Bernardara, P., Mouchel, J. M., and Hubert, G.: Indicators for identification of urban flooding vulnerability, Nat. Hazards Earth Syst. Sci., 6, 553-561, doi:10.5194/nhess-6-5532006, 2006.

Bayer, A.: Methoden zur Abschätzung des Risikos einer technischen Anlage, Fridericana, 27, 3-21, 1980 (in German).

Blättler, R.: Rezente fluviale Morphodynamik im Stubaital, Tirol, Würzburger Geographische Arbeiten, Heft 90, 1995 (in German).

BMLFUW (Bundesministerium für Land- und Forstwirtschaft, Umwelt und Wasserwirtschaft) (Ed.): Analyse der Hochwasser- ereignisse vom August 2002 - Flood Risk, WP Naturgefahren BWV TP 07, 2004 (in German).

BMLFUW (Bundesministerium für Land- und Forstwirtschaft, Umwelt und Wasserwirtschaft) (Ed.): Hochwasser 2005 Ereignisdokumentation, 2006 (in German).

BMLFUW (Bundesministerium für Land- und Forstwirtschaft, Umwelt und Wasserwirtschaft) (Ed.): Kosten-NutzenUntersuchungen im Schutzwasserbau - Richtlinie, available at: http://wasser.lebensministerium.at/article/articleview/49301/1/ 14462 (last access: 6 October 2010), 2009 (in German).

Bohle, H. G. and Glade, T.: Vulnerabilitätskonzepte in Sozial- und Naturwissenschaften, in: Naturrisiken und Sozialkatastrophen, edited by: Felgentreff, C. and Glade, T., Springer-Verlag, 99119, 2008 (in German).

Blöschl, G., Merz, R., Humer, G., Hofer, M., Hochhold, A., and Wührer, W.: HORA Hochwasserrisikoflächen Österreich - Hydrologische Arbeiten, Endbericht an das Bundesministerium für Land- und Forstwirtschaft, Umwelt und Wasserwirtschaft, 2006 (in German).

Bronstert, A.: Möglichkeiten zur Minderung des Hochwasserrisikos durch Nutzung von Flutpoldern an Havel und Oder, Brandenburgische Umwelt Berichte, Heft 15, 2004 (in German).

Buck, W., Kron, A., and Wetzel, A.: Nutzen-Kosten-Untersuchung für ein Sturmflutwerk, "Was wäre wenn" - Untersuchung bei der Schadensermittlung von Hochwasserschutzmaßnahmen, KW Korrespondenz Wasserwirtschaft, Heft 5, 2008 (in German).

BWG (Bundesamt für Wasser und Geologie): Hilfe-Assistent zum Excel-Tool Methode BWG für die Abschätzung des Schadenpotentials Überschwemmung und Übermurung, available at: http://www.bafu.admin.ch/naturgefahren/01923/01954/ index.html?lang=de (last access: 6 October 2010), 2006 (in German).

BWK (Bund der Ingenieure für Wasserwirtschaft, Abwasserwirtschaft und Kulturbau): Hochwasserschadenpotenziale, BWK-Berichte 1/2001, 2001 (in German).

Clark, D. E., Novotny, V., Griffin, R., Booth, D., Bartosava, A., Daun, M. C., and Hutchinson, M.; Willingness to pay for flood and ecological risk reduction in an urban watershed, Water Sci. Technol., 45(9), 235-242, 2002.

Council of the European Parliament: Directive 2007/60/EC of the European Parliament and of the Council of 23 October 2007 on the assessment and management of flood risks, 2007.

Dawson, R. W.: Performance based management of flood defence systems, Ph.D. thesis, University of Bristol, UK, 2003.

Dikau, R. and Weichselgartner J.: Der unruhige Planet - Der Mensch und die Naturgewalten, Wissenschaftliche Buchgesellschaft, 2005 (in German).

Douglas, J.: Physical vulnerability modelling in natural hazard risk assessment, Nat. Hazards Earth Syst. Sci., 7, 283-288, doi:10.5194/nhess-7-283-2007, 2007.

DWA (German Association for Water, Wastewater and Waste): Arbeitshilfe: Hochwasserschadensinformationen, 2008 (in German).

Embrechts, P., Furrer, H., and Kaufmann, R.: Different Kinds of Risk, in: Handbook of Financial Time Series, edited by: Andersen, T.,G., Davis, R. A., Kreiss, J.-P., and Mikosch, T.: SpringerVerlag, 729-752, 2009.

Emschergenossenschaft (Ed.): Hochwasser-Aktionsplan Emscher, Methodik der Schadensermittlung, available at: 
http://www.eglv.de/fileadmin/EmscherGenossenschaft/2.

3_Flussgebietsmanagement/Karten_Anlage/Methodik_der_

Schadensermittlung/methodik_schadensermittlung.pdf

(last access: 6 October 2010), 2004 (in German).

Felgentreff, C. and Dombrovsky, W. R.: Hazard-, Risiko- und Katastrophenforschung, in: Naturrisiken und Sozialkatastrophen, edited by: Felgentreff, C. and Glade, T., Springer-Verlag, 13-29, 2008 (in German).

FEMA (Federal Emergency Management Agency): Report on costs and benefits of natural hazard mitigation, available at: http: //www.fema.gov/pdf/library/haz_cost.pdf (last access: 6 October 2010), 1998.

Freistaat Sachsen: Bericht der Sächsischen Staatsregierung zur Hochwasserkatastrophe im August 2002 (Report of the Federal Government of Saxony on the Flood Catastrophe in August 2002), 2003 (in German).

Fuchs, S.: Susceptibility versus resilience to mountain hazards in Austria - paradigms of vulnerability revisited, Nat. Hazards Earth Syst. Sci., 9, 337-352, doi:10.5194/nhess-9-337-2009, 2009.

Fuchs, S. and McAlpin, M. C.: The net benefit of public expenditures on avalanche defence structures in the municipality of Davos, Switzerland, Nat. Hazards Earth Syst. Sci., 5, 319-330, doi:10.5194/nhess-5-319-2005, 2005.

Fuchs, S., Heiss, K., and Hübl, J.: Towards an empirical vulnerability function for use in debris flow risk assessment, Nat. Hazards Earth Syst. Sci., 7, 495-506, doi:10.5194/nhess-7-4952007, 2007.

Gewalt, M., Klaus, J., Peerbolte, E. B., Pflügner, W., Schmitke, R. F., and Verhagen, L.: EUROflood - Technical Annex 8. Economic Assessment of Flood Hazards, Regional Scale Analysis Decision Support System (RSA-DSS), 1996.

Giardono, A.: Wetterlagenanalyse der Starkniederschlagsereignisse in Nordtirol zwischen 1971 und 2002, unpublished thesis, Institute of Meteorology and Geophysics, University Innsbruck, Austria, 2007 (in German).

Glade, T. and Crozier, M.: A review of scale dependency in landslide hazard and risk analysis, in: Landslide hazard and risk, edited by: Glade, T., Anderson, M., and Crozier, M., Wiley, Chichester, UK, 75-138, 2005.

Green, C., van der Veen, A., Wierstra, E., and Penning-Rowsell, E. C.: Vulnerability Refindes, in: Floods Across Europe. Hazard Assessment, Modelling and Management, edited by: PenningRowsell, E. C. and Fordham, M., Middlesex University Press, 32-68, 1994.

GVB (Gebäudeversicherung Bern): Das Schadenpotenzial aus Naturgefahren: Womit muss der Kanton Bern rechnen?, Zusammenfassung der Resultate einer wegweisenden Studie mit Pilotcharakter, Information for the medias, 11 May 2001, 2001 (in German).

Haimes, Y. Y.: On the Complex Definition of Risk: A Systemsbased Approach, Risk Anal., 29, 1647-1654, 2009.

Hall, J. W. and Solomatine, D.: A framework for uncertainty analysis in flood risk management decisions, Int. J. River Basin Management, 6(2), 85-98, 2008.

Hall, J. W., Dawson, R. J., Sayers, P. B., Rosu, C., Chatterton, J. B., and Deakin, R.: A Methodology for National-Scale Flood Risk Assessment, P. I. Civil Eng.-Water, 156(3), 235-247, 2003.

Hamann, M. and Reese, S.: Wertermittlung und Schadensanal- yse als Instrument für die Küstenschutzplanung in SchleswigHolstein, Bremer Beiträge zur Geographie und Raumplanung, 36, 139-147, 2000 (in German).

Heinimann, H. R., Hollenstein, K., Kienholz, Krummenacher, B., and Mani, P.: Methoden zur Analyse und Bewertung von Naturgefahren, edited by: Bundesamt für Umwelt, Wald und Landschaften (BUWAL), Umwelt-Materialien Nr. 85, 248 pp. 1998 (in German).

Hennegriff, W.: Ermittlung und Bewertung von Hochwasserschutzwirkungen, Proceeding of DWA-Symposium Hochwasserschadeninformationen: Neues und Bewährtes, Contribution, 3, 1-17, 2008 (in German).

Hennegriff, W., Kolokontris, V., Weber, H., and Bartels, H.: Klimawandel und Hochwasser. Erkenntnisse und Anpassungsstrategien beim Hochwasserschutz, KA - Abwasser, Abfall, 53(8), 770-779, 2006 (in German).

Hilker, N., Hegg, C., Zappa, M.: Unwetterschäden in der Schweiz 1972-2007 mit besonderer Betrachtung des Augusthochwassers 2005, INTERPRAEVENT Proceedings 2008, 1, 99-110, 2008 (in German).

Hollenstein, K.: Analyse, Bewertung und Management von Naturrisiken, vdf Hochschulverlag an der ETH, 1997 (in German).

Hollenstein, K.: Reconsidering the risk assessment concept: Standardizing the impact description as a building block for vulnerability assessment, Nat. Hazards Earth Syst. Sci., 5, 301-307, doi:10.5194/nhess-5-301-2005, 2005.

Hollenstein, K., Bieri, O., and Stückelberger, J.: Modellierung der Vulnerability von Schadenobjekten gegenüber Naturgefahrenprozessen, BUWAL/Eidgenössische Forstdirektion Schutzwald und Naturgefahren, 2002 (in German).

Horritt, M. S. and Bates, P. D.: Evaluation of 1D and 2D numerical models for predicting river flood inundations, J. Hydrol., 268, 87-99, 2002.

Huttenlau, M. and Stötter, J.: Ermittlung des monetären Werteinventars als Basis von Analysen naturgefahreninduzierter Risiken in Tirol, Geographica Helvetica, 2/2008, 85-93, 2008 (in German).

Huttenlau, M. and Stötter, J.: Kumulatives Schadenpotenzial von worst-case Szenarien in Tirol, Final project report, alpS - Centre for Natural Hazard and Risk Management, 2009 (in German).

ICPR (International Commission for the protection of the Rhine): Atlas on the risk of flooding and potential damage due to extreme floods of the Rhine, available at: http://iksr.de/index.php?id=344 (last access: 6 October 2010), 2001.

IWHW (Institute of Water Management, Hydrology and Hydraulic Engineering of the University of Natural Resources and Applied Life Sciences, Vienna) (Ed.): Dokumentation der Hochwasserereignisse 2005 in Österreich im Bereich der Bundeswasserbauverwaltung, 2006 (in German).

IWK (Institut für Wasserwirtschaft und Kulturtechnik Universität Karlsruhe): Auswertung der HOWAS-Datenbank, HY 98/15, 1999 (in German).

Jonkman, S. N. and Vrijling, J. K.: Loss of life due to floods, J. Flood Risk Manage., 1, 43-56, 2008.

Jonkman, S. N., Vrijling, J. K., and Vrouwenvelder, A. C. W. M.: Methods for the estimation of loss of life due to floods: A literature review and a proposal for a new method, Nat. Hazards, 46, 353-389, 2008.

Kantz, H., Altmann, E. G., Hallerberg, S., Holstein, D., and Rigert, 
A.: Dynamical Interpretation of Extreme Events: Predictability and Predictions, in: Extreme Events in Nature and Society, edited by: Albeverio, S., Jentsch, V., and Kantz, H., Springer, 69-93, 2006.

Kienholz, H.: Analyse und Bewertung alpiner Naturgefahren. Eine Daueraufgabe im Rahmen des integralen Risikomanagements, Geographica Helvetica, 1/2005, 3-15, 2005 (in German).

Kleist, L., Thieken, A. H., Köhler, P., et al.: Estimation of the regional stock of residential buildings as a basis for a comparative risk assessment in Germany, Nat. Hazards Earth Syst. Sci., 6, 541-552, doi:10.5194/nhess-6-541-2006, 2006.

Knebl, M. R., Yang, Z. L., Hutchison, K., and Maidment, D. R.: Regional scale flood modelling using NEXRAD rainfall, GIS, and HEC-HMY/RAS: a case study for the San Antonio River Basin Sommer 2002 storm event, J. Environ. Manage., 75, 325336, 2005.

Koivumäki, L., Alho, P., Lotsari, E., Käyhkö, J., Saari, A., and Hyyppä, H.: Uncertainties in flood risk mapping: a case study on estimating building damages for river flood in Finland, Journal of Flood Risk Management, 3, 166-183, 2010.

Kok, M., Huizinga, H. J., Vrouwenvelder, A. C. W. M., and Batendregt, A.: Standaardmethode 2004 Schade en Slachtoffers als gevolg van overstromingen, http://library.wur.nl/WebQuery/ hydrotheek/lang/1874298 (last access: 6 October 2010), 2004 (in Dutch).

Kreibisch, H., Petrow, T., Thieken, A. H., Müller, M., and Merz, B.: Consequences of the extreme flood event of August 2002 in the City of Dresden (Germany), in: Sustainable Water Management Solutions for Large Cities, edited by: Savic, D. A., Marino, M. A., Savenije, H. H. G., and Bertoni, J. C., IAHS Publications, 293, 164-173, 2005a.

Kreibich, H., Thieken, A. H., Petrow, Th., Mller, M., and Merz, B.: Flood loss reduction of private households due to building precautionary measures - lessons learned from the Elbe flood in August 2002, Nat. Hazards Earth Syst. Sci., 5, 117-126, doi:10.5194/nhess-5-117-2005, 2005b.

Kremer, E.: On the Probable Maximum Loss, Blätter der DGVFM (Deutschen Gesellschaft für Versicherungs- und Finanzmathematik e.V.), 19, 201-205, 1990.

Kremer, E.: More on the Probable Maximum Loss, Blätter der DGVFM (Deutschen Gesellschaft für Versicherungs- und Finanzmathematik e.V.), 21, 319-326, 1994.

Kron, W.: Versicherung von Hochwasserschäden, in: HochwasserHandbuch: Auswirkungen und Schutz, edited by: Platt, H., Springer-Verlag, 461-504, 2001 (in German).

Kron, W.: Zunehmende Überschwemmungsschäden: Eine Gefahr für die Versicherungswirtschaft?, ATV-DVWK-Bundestagung Würzburg, 47-63, 2004 (in German).

Kron, W.: Storm surges, river floods, flash floods - Losses and Prevention Strategies, edited by: Munich Re: Schadenspiegel 3/2005 - Special feature issue: Risk factor of water, 8-13, German version is alternatively available at: http://www.wwa-ro.bayern.de/aktuelles/doc/hochwasserforum/ kron_hochwasservorsorge.pdf (last access: September 2009), 2005.

Kron, W. and Thumerer, T.: Überschwemmung in Deutschland: Risikomodellierung und Kumul-Kontrolle für HochwasserGebiete, Versicherungswirtschaft, 17, 1371-1377, 2001 (in German).
Kron, W. and Willems W.: Flood risk zoning and loss accumulation analysis for Germany, International Commission for the Hydrology of the Rhine basin, Proceedings International Conference on Flood Estimation, 549-558, 2002.

LAWA (Länderarbeitsgemeinschaft Wasser): Empfehlungen der Länderarbeitsgemeinschaft Wasser zur Aufstellung von Hochwasser-Gefahrenkarten, 2006 (in German).

Leiter, A. M.: Monetary risk valuation in context with natural hazards, Ph.D. thesis, University of Innsbruck, 2006.

Loat, R. and Petrascheck, A.: Berücksichtigung der Hochwassergefahren bei raumwirksamen Tätigkeiten, edited by: Bundesamt für Wasserwirtschaft, Bundesamt für Raumplanung, Bundesamt für Umwelt, Wald und Landschaften: Empfehlungen 1997, 1997 (in German).

Meier, I. M.: Leben mit dem Hochwasser: Ausgewählte Hochwasserereignisse des 20. Jahrhunderts im Tiroler Lechtal, unpublished thesis, Department of Geography, University Innsbruck, Austria, 2002 (in German).

Melchers, R.: Safety and risk in structural engineering, Prog. Struct. Eng. Mat., 4(2), 193-202, 2002.

Merz, B.: Hochwasserrisiken: Grenzen und Möglichkeiten der Risikoabschätzung, E. Schweizerbart'sche Verlagsbuchhandlung, 2006 (in German).

Merz, B. and Thieken, A. H.: Flood Risk Analysis: Concepts and Challenges, Österreichische Wasser- und Abfallwirtschaft, 3-4, 27-34, 2004.

Meyer, V.: Methoden der Sturmflut-Schadenpotenzialanalyse an der deutschen Nordseeküste, Ph.D. thesis, University of Hannover, Germany, 2005 (in German).

Meyer, V. and Messner, F.: National Flood Damage Evaluation Methods - A Review of Applied Methods in England, the Netherlands, the Czech Republic and Germany, UFZ-Discussion Papers, available at: http://www.floodsite.net/html/partner_area/ project_docs/DP_Meyer_Messner_national_flood_damage evaluation_methods24112005.pdf (last access: 6 October 2010), 2005.

Meyer, V. and Messner, F.: Guidelines for direct, tangible flood damage evaluation, in: Evaluating flood damages: guidance and recommendations on principles and methods, edited by: Messner, F., Penning-Rowsell, E., Green, C., Meyer, V., Tunstall, S., and van der Veen, A., Report Number: T09-06-01, 22-73, available at: http://www.floodsite.net/html/partner_area/project_docs/ T09_06_01_Flood_damage_guidelines_D9_1_v2_2_p44.pdf (last access: 6 October 2010), 2007.

Müller, M. and Thieken, A.: Elementartarife können weiter differenziert werden, Versicherungswirtschaft, 2/2005, 145-148, 2005 (in German).

Müller, M.: Überschwemmungsschadenmodellierung der Deutschen Rückversicherung AG, Presentation at Tiroler Versicherung (Tyrolean Insurance Company), 2009 (in German).

Müller-Mahn, D.: Von "Naturkatastrophen" zu "Complex Emergencies" - Die Entwicklung integrativer Forschungsansätze im Dialog mit der Praxis, edited by: Müller-Mahn, D. and Wardenga, U., Möglichkeit und Grenzen integrativer Forschungsansätze Physischer Geographie und Humangeographie, forum ilf, 69-78, 2005 (in German).

Müller-Mahn, D.: Perspektiven der geographischen Risikoforschung, Geographische Rundschau, 10/2007, 4-11, 2007 (in German). 
Munich Re: Schadenspiegel - Special feature issue: Risk factor water, 2005.

Munich Re: Topic Geo - Natural catastrophes 2006: Analyses, assessments, positions, 2007.

MURL (Ministerium für Umwelt, Raumordnung und Landwirtschaft des Landes Nordrhein-Westfalen) (Ed.): Hochwasserschadenpotenziale am Rhein in Nordrhein-Westfalen, Abschlussbericht, 2000 (in German).

Panayotis, P., Kortenhaus, A., Swerpel, B., and Jiménez, J. A.: Review of Flood Hazard Mapping, Report Number: T03-0701, available at: http://www.floodsite.net/html/partner_area/ project_docs/T03_07_01_Review_Hazard_Mapping_V4_3_P01. pdf (last access: 6 October 2010), 2008.

Papathoma-Köhle, M., Neuhäuser, B., Ratzinger, K., Wenzel, H., and Dominey-Howes, D.: Elements at risk as a framework for assessing the vulnerability of communities to landslides, Nat. Hazards Earth Syst. Sci., 7, 765-779, doi:10.5194/nhess-7-7652007, 2007.

Pender, G., Bates, P. D., Wright, N. G., Falconer, R., and Lin, B.: An Overview of the Structure and Inundation Modelling Activities of the Flood Risk Management Research Consortium, edited by: van Alphen, J., can Beck, E., and Taal, M., Floods, from Defence to Management, Taylor \& Francis, 147-152, 2006.

Penning-Rowsell, E. C. and Green, C.: Enhanced appraisal of flood elevation benefits: New approaches and lessons from experiences, in: Floods, edited by: Parker, D. J., Routledge, 214-237, 2000a.

Penning-Rowsell, E. C. and Green, C.: New insights into the appraisal of flood alleviation benefits: (1) Flood damage and flood loss information, Water Environ. J., 14(5), 347-353, $2000 \mathrm{~b}$.

Penning-Rowsell, E. C., Johnson, C., Tunstall, S., Tapsell, S., Morris, J., Chatterton, J., Coker, A., and Green, C.: The Benefits of flood and coastal defense: techniques and data for 2003, Middlesex University Press, 2003.

Plate, E. J.: Stochastic design in hydraulics: concepts for a broader application, in: Stochastic hydraulics'92, edited by: Kuo, J. T. and Lin, G. F., Proceedings 6th IAHR International Symposium on Stochastic Hydraulics, Taipei, Taiwan, 663-670, 1992.

Pohl, J.: Die Entstehung der geographischen Hazardforschung, in: Naturrisiken und Sozialkatastrophen, edited by: Felgentreff, C. and Glade, T., Springer-Verlag, 47-62, 2008 (in German).

Pohl, J. and Geipel, R.: Naturgefahren und Naturrisiken, Geographische Rundschau, 1/2002, 4-8, 2002 (in German).

Reese, S. and Markau, H.-J.: Mikroskalige Wertermittlung in sturmgefährdeten Küstenniederungen, Jahrbuch der Hafenbautechnischen Gesellschaft, Heft 54, undisclosed, available at: http://www.sterr.geographie.uni-kiel.de/mare/htg.pdf (last access: 6 October 2010), 2004 (in German).

Renn, O. and Walker, K.: Global Risk Governance: Concepts and Practise Using the IRGC Framework, Springer, 2008.

Samuels, P., Gouldby, B., Klijn, F., Messner, F., van Os, A., Sayers, P., Schanze, J., and Udale-Clarke, H.: Language of Risk Project Definitions, http://www.floodsite.net/html/partner_area/ project_docs/FLOODsite_Language_of_Risk_v4_0_P1(1).pdf (last access: please complete), 2009.

Schmitke, R. F.: Sozio-ökonomische Schäden von Hochwasserkatastrophen, Wasserbau-Mitteilungen der Technischen Hochschule Darmstadt, 40/1995, 143-156, 1995 (in German).
Schrott, L. and Glade, T.: Frequenz und Magnitude natürlicher Prozesse, in: Naturrisiken und Sozialkatastrophen, edited by: Felgentreff, C. and Glade, T., Springer-Verlag, 133-140, 2008 (in German).

Seibert, P., Frank, A., and Formayer, H.: Synoptic and regional patterns of heavy precipitation in Austria, Theor. Appl. Climatol., 87(1-4), 139-153, 2007.

Smith, K. and Ward, R.: Floods - Physical Processes and Human Impacts, Wiley, 1998.

Staatliches Umweltamt Minden (Ed.): Hochwasser-Aktionsplan Werre, Erläuterungsbericht, undisclosed, available at: http:// www.stua-mi.nrw.de/hwap/Erlaeuterungsbericht-HWAP-Werre. pdf, last access: 6 October 2010 (in German).

Staatliches Umweltamt Münster (Ed.): Bericht zum Hochwasseraktionsplan Werse, Band 2: Schadenpotenziale, Maßnahmen und Wirkungen, available at: http://www.umweltamt.org/klue/html/ download_bericht/HWAPWerse_Band2.pdf, last access: 6 October 2010 (in German).

Statistik Austria (Ed.): Volkszählung 2001 - Hauptergebnisse Tirol, 2004 (in German).

Thieken, A., Müller, M., Kreibisch, H., and Merz, B.: Flood damages and influencing factors: New insights from the August 2002 flood in Germany, Water Resour. Res., 41(12), 1-16, 2005.

Thieken, A. H., Seifert, I., Elmer, F., Kreibisch, H., Ackermann, V., and Schwarze, R.: Vorschläge zur Organisation von Erhebungen sowie zur Datenaufbereitung und Datenhaltung, in: Hochwasserschäden: Erfassung, Aschätzung, Vermeidung, edited by: Thieken, A. H., Seifert, I., and Merz, B., Oekom Verlag, 139-150, 2010 (in German).

Völkening, E. and Odenhausen, M.: Zur Rückversicherung von Naturgefahren in Deutschland, Zeitschrift für Versicherungswesen, 21/1, 632-636, 2003 (in German).

VVO (Austrian Insurance Association): Index-linking recommendation for the property insurance, Notice in writing: 27 April 2007, 2007.

Weichhart, P.: Risiko - Vorschläge zum Umgang mit einem schillernden Begriff, Berichte zur deutschen Landeskunde, 81(3), 201-214, 2007 (in German).

Weichselgartner, J.: Naturgefahren als soziale Konstruktion. Eine geographische Betrachtung der gesellschaftlichen Auseinandersetzung mit Naturrisiken, Shaker Verlag, 2002 (in German).

Willems, W.: HORA - Teilprojekt A: Hydraulische Arbeiten (HORA I), Teilprojekt B: HORA-Kumul (HORA II), Endbericht an das Bundesministerium für Land- und Forstwirtschaft, Umwelt und Wasserwirtschaft, 2006 (in German).

Woo, G.: Natural catastrophe probable maximum loss, British Actuarial Journal, 8(5), 943-959, 2002.

Woodhead, S., Asselman, N., Zech, Y., Soarez-Frazao, S., Bates, B., and Kortenhaus, A.: Evaluation of Inundation Models, available at: http://www.floodsite.net/html/partner_area/project_docs/T08_ 07_01_Inundation_Model_Evaluation_M8_1_V1_7_P15.pdf (last access: 6 October 2010), 2007.

Zahnen, B.: Schleichende Naturrisiken als geographisches Problem der Zeit. Ein Beitrag zur Theorie der Geographie, Geographische Revue, 1/2008, 15-29, 2008 (in German).

Zhai, G., Sato, T., Fukuzono, T., Ikeda, S. and Yoshida, K.: Willingness to pay for flood risk reduction and its determinants in Japan, J. Am. Water Resour. As. (JAWRA), 42(4), 927-940, 2007. 